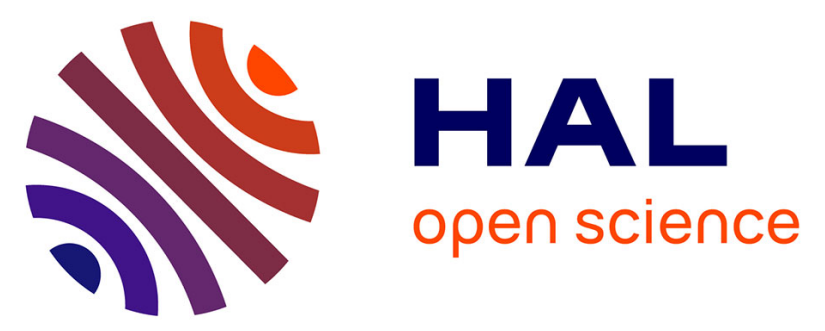

\title{
High-resolution sedimentary record of the last deglaciation from a high-altitude lake in Ethiopia
}

Jean-Jacques Tiercelin, Elisabeth Gibert, M. Umer, Raymonde Bonnefille, Jean-Robert Disnar, A.-M. Lézine, D. Hureau-Mazaudier, Yves Travi, Didier

Kéravis, H.F. Lamb

\section{To cite this version:}

Jean-Jacques Tiercelin, Elisabeth Gibert, M. Umer, Raymonde Bonnefille, Jean-Robert Disnar, et al. High-resolution sedimentary record of the last deglaciation from a high-altitude lake in Ethiopia. Quaternary Science Records, 2008, 27 (5-6), pp.449-467. 10.1016/j.quascirev.2007.11.002 . insu00272039

\section{HAL Id: insu-00272039 \\ https://hal-insu.archives-ouvertes.fr/insu-00272039}

Submitted on 10 Apr 2008

HAL is a multi-disciplinary open access archive for the deposit and dissemination of scientific research documents, whether they are published or not. The documents may come from teaching and research institutions in France or abroad, or from public or private research centers.
L'archive ouverte pluridisciplinaire HAL, est destinée au dépôt et à la diffusion de documents scientifiques de niveau recherche, publiés ou non, émanant des établissements d'enseignement et de recherche français ou étrangers, des laboratoires publics ou privés. 


\title{
High-resolution sedimentary record of the last deglaciation from a high-altitude lake in Ethiopia
}

\author{
J.-J. Tiercelin ${ }^{a}$, E. Gibert ${ }^{b}$, M. Umer ${ }^{\mathrm{c}}$, R. Bonnefille ${ }^{\mathrm{d}}$, J.-R. Disnar ${ }^{\mathrm{e}}$, A.-M. Lézine ${ }^{\mathrm{f}}$, D. \\ Hureau-Mazaudierg, Y. Travi ${ }^{\text {h }}$, D. Keravis ${ }^{\mathrm{e}}$ and H.F. Lamb ${ }^{\mathrm{i}}$
}

${ }^{a}$ UMR CNRS 6118 Géosciences Rennes, Equipe «Bassins sédimentaires», Université de Rennes 1, Campus de Beaulieu, Bât. 15, 35042 Rennes, France

${ }^{\mathrm{b}}$ UMR CNRS/UPS 8148-IDES, Université Paris-Sud, Bât. 504, 91405 Orsay cedex, France

${ }^{c}$ Department of Earth Sciences, Addis Ababa University, P.O. Box 1176, Addis Ababa, Ethiopia

${ }^{\mathrm{d}}$ CEREGE, Europôle de l'Arbois, B.P. 80, 13545 Aix-en-Provence cedex 04, France

${ }^{\mathrm{e}}$ Institut des Sciences de la Terre d'Orléans (I.S.T.O.), UMR 6113 CNRS, Bâtiment

Géosciences, Université d'Orléans, BP 6759, 45067 Orléans Cédex 2, France

fUMR CNRS-CEA-UVSQ 1572, Laboratoire des Sciences du Climat et de l'Environnement, Orme des Merisiers, 91191 Gif-sur-Yvette cedex, France

${ }^{g}$ UMR CNRS/UBO 6538 «Domaines Océaniques», Institut Universitaire Européen de la Mer, place Nicolas Copernic, 29280 Plouzané, France

hFaculté des Sciences d'Avignon, Laboratoire d'Hydrogéologie, 83 rue Pasteur, 84000

Avignon, France

${ }^{\mathrm{i}}$ Institute of Geography and Earth Sciences, University of Wales, Aberystwyth SY23 3DB, UK

\begin{abstract}
Sedimentological and geochemical studies conducted on a 15.82-m long core collected from Lake Garba Guracha (Ethiopia) associated with a precise AMS- ${ }^{14} \mathrm{C}$ time-scale document a unique record of the sedimentary processes linked to the progressive retreat of a high-altitude glacier in the Bale Mountains since 17,000 yr cal BP. Lake sedimentation is interpreted as the result of discharges of meltwater and glaciogenic sediment which progressively filled the accommodation space generated by glacier retreat within the basin. Monogenic sediment originated from glacial erosion of the trachytic tuff forming the cirque floor. Ice melting ended progressively between 12,600 and $11,800 \mathrm{cal} \mathrm{BP}$, as suggested by the decrease in sedimentation energy followed by a sharp change in sedimentary facies. From 11,800 cal BP, the lake reached its maximum development and clastic input was replaced by organic-rich sedimentation. This relates to a major increase of lake productivity, which lasted up to 4500 cal BP. From this period, a lowering in productivity reflects the widespread dryness which occurred throughout the East African tropics.
\end{abstract}

\section{Introduction}

Several high mountain ranges in Africa carry evidence of Quaternary glaciations, the beststudied sites being in East Africa (Shanahan and Zreda, 2000; Kaser and Osmaston, 2002; Osmaston and Harrison, 2005) (Fig. 1a,b). Among them are the Bale Mountains of southcentral Ethiopia, one of the highest regions of East Africa, that reach a maximum elevation of $4400 \mathrm{~m}$ asl at the Tullu Dimtu peak (Fig. 1). South-central Ethiopia corresponds to a wide plateau at 2000-3000 m formed by early Tertiary age tabular lava flows that support several large volcanoes of Plio-Pleistocene age rising to altitudes of over $4000 \mathrm{~m}$. This plateau is 
deeply dissected by the NNE-oriented main ethiopian rift (MER) that represents the northernmost segment of the Eastern Branch of the East African Rift System. The rift floor lies at a mean elevation of $1550 \mathrm{~m}$ and is characterized by a suite of freshwater to moderately saline tectonic or volcanic lakes (Fig. 1c). Extensive palaeoclimate research has been conducted in this "Lakes Region" during the last three decades (Grove and Goudie, 1971; Gasse and Street, 1978; Street, 1979; Lézine and Bonnefille, 1982; Gillespie et al., 1983; Bonnefille et al., 1986; Mohammed and Bonnefille, 1991; Mohammed, 1992; Alessio et al., 1996; Gibert et al., 1999; Le Turdu et al., 1999; Lamb, 2001; Benvenuti et al., 2002; Chalié and Gasse, 2002; Gibert et al., 2002; Legesse et al., 2002; Lamb et al., 2004). These studies have demonstrated that the MER region was highly sensitive to Late Quaternary climate changes but also to non-climatic forcings. Active tectonics and basin subsidence, paroxysmic explosive volcanic phases and associated hydrothermalism on the rift floor controlled at times the evolution of lacustrine domains (Le Turdu et al., 1999; Telford and Lamb, 1999; [Lamb et al., 2000] and [Lamb et al., 2004]; Benvenuti et al., 2002).

In comparison to the rift floor, the southern-central Ethiopian Plateau has mainly been studied from the geomorphological and palynological point of view, providing evidence for its glacial and post-glacial history (Löffler, 1978; Hamilton, 1982; Bonnefille and Hamilton, 1986; Mohammed, 1992; Bonnefille and Mohammed, 1994; Grab, 2002; Osmaston and Harrison, 2005; Osmaston et al., 2005; Mitchell et al., 2006). These authors indicate that Quaternary glaciations affected the highest mountain ranges of Ethiopia, including the Bale Mountains which show clear evidence for a central plateau ice cap and valley glaciers possibly dating at least from the last glacial maximum (LGM) (Fig. 1a). In such a region, a new potential site to obtain a high-altitude palaeoenvironmental record was prospected in May 2001. A $15.82 \mathrm{~m}$ long core (GG-I) was collected in Lake Garba Guracha, one of the highest (3950 m) permanent lakes in south-central Ethiopia (Fig. 1a,d). The study of this core has allowed a reassessment of the age of deglaciation in this part of Ethiopia and of the Lateglacial to Holocene lacustrine evolution in response to global climate change. This paper presents a sediment and organic matter analysis of the Garba Guracha-I core calibrated with a detailed AMS $-{ }^{14} \mathrm{C}$ chronology, while pollen record and vegetation history of the Bale Mountains are presented in an other paper (Umer et al., 2007).

\section{General setting of the Bale Mountains}

The Bale Mountains belong to the Bale-Arsi massif that forms the western section of the south-eastern Ethiopian highlands. They represent the northernmost high mountain range of Africa (Troll, 1973), and correspond between $6^{\circ} 40^{\prime}$ and $7^{\circ} 10^{\prime}$ lat $\mathrm{N}$ and $39^{\circ} 30^{\prime}$ and $40^{\circ}$ long $\mathrm{E}$ to the tabular Sanetti Plateau formed by early Tertiary basalts and trachytes, with altitudes of 4000-4200 m (Mohr, 1971; [Gobena et al., 1996] and [Gobena et al., 1998]). Several peaks rise above the plateau, Mount Batu (Dimtu Guda) (4370 m) and Tullu Dimtu, that culminates at $4377 \mathrm{~m}$ and is the second highest peak in Ethiopia (Messerli et al., 1977; Dodola topographic map, 1:250,000). The northern slope of the Bale Mountains is deeply dissected by the Togona and Kaficha river valleys. This area contains numerous glacial lakes and bogs (Löffler, 1978), including Lake Garba Guracha (also Gourach or Gouracha, meaning "Black Lake" in the local Oromo language) located at $6^{\circ} 52^{\prime}$ lat $\mathrm{N}$ and $39^{\circ} 49^{\prime}$ long E (Fig. 1c, d).

On the Bale Mountain, as in the whole Horn of Africa, alternating wet and dry seasons follow the annual movements of the Inter Tropical Convergence Zone (Griffiths, 1972; Nicholson, 1996). In summer (June-September), the ITCZ is located in northern Ethiopia and the northwest and central parts of the country are under the influence of the southwesterly and 
southerly monsoon flow. Between October and March, the ITCZ is located south of Ethiopia inducing a northerly flow of dry, cold air from the Arabian continent. During this time, colder temperatures are recorded in the highlands. This southward flow brings some moisture from the Arabian Sea and Northern Indian Ocean up to the eastern lowlands bordering the southeastern plateau and produce rainfall in the months of October, November and December. Rainfall generally varies from about $1000 \mathrm{~mm}$ on the northern slope to about $800 \mathrm{~mm}$ on the southern one. However altitude and aspect strongly affect the amount and distribution of rainfall and temperature on the mountains. Seasonal rainfall distribution is more even on the southern slope as compared to the northern one. In this region, air temperatures have a wide diurnal range but slight seasonal variation (Löffler, 1978). There are no direct records of temperature and rainfall in the Garba Guracha Lake area. The mean annual temperature is $11.8^{\circ} \mathrm{C}$ at Dinsho (elevation $3170 \mathrm{~m}$ ) (Fig. 1c), and the mean minimum temperature of the coldest month (January) is $0.6{ }^{\circ} \mathrm{C}$ at the same location (Hillman, 1986, cited in Wesche, 2003). Frost is common at 4000-4200 m. Mean rainfall data from nearby meteorological sites located at lower altitude (2700-3500 m) vary between 800 and $1400 \mathrm{~mm}$. At the Garba Guracha site, the vegetation essentially belongs to the upper Ericaceous and Afro-alpine belts (Miehe and Miehe, 1994; Umer et al., 2007).

\section{Limnogeological characteristics of Lake Garba Guracha}

Lake Garba Guracha was first described by Werdecker (1962) and Löffler (1978). It is a small, roughly rectangular ( $\sim 500 \mathrm{~m}$ long, $\sim 300 \mathrm{~m}$ wide) NNE-oriented lake lying in a typical glacial cirque at the end of a side valley of the upper Togona valley (Fig. 1, Fig. 2 and Fig. 3). This glacial cirque is bounded to the south-east and south by up to 140-m high cliffs and steep slopes formed by basaltic lavas overlying a several tens of $m$ thick trachytic tuff unit that outcrops only on the southern and southeastern slopes of the cirque but form a large part of the cirque base (Fig. 2 and Fig. 3). At its northeastern end, the cirque offers a rock bar morphology typical for a glacial cirque. This rock bar is partially boulder-covered. It acts as lake outlet towards the Togona valley during periods of maximum lake level (Fig. 2 and Fig. $3)$.

The lake watershed is very small $\left(0.15 \mathrm{~km}^{2}\right.$; lake/watershed surface ratio $\left.=2\right)$ and corresponds to the cliffs and steep slopes at the south end of the cirque. These slopes are locally covered by thick screes of basalt debris, that are for a large part stabilized but remain active along the southeast cliffs (Fig. 3d). Several springs and small streams merge from the southern slope and flow towards the southern edge of the lake where they form a small meandering fluvial system through a $0.5 \mathrm{~km}$ long flat, marshy alluvial plain (Fig. 2 and Fig. 3). The present-day lake shoreline is characterized by immature, coarse clastic material possibly forming the distal fringe of the basaltic screes carpeting the lower catchment. The southern shoreline offers a rectilinear profile with well-sorted clean sands as a result of wave action generated by the strong northerly winds. The offshore lake sedimentation is characterized by a dark-green organic-rich mud (TOC up to 11\%) that accumulate in the axial part of the basin as a consequence of continuous vegetation cover around the lake that precludes any terrigenous input (Fig. 2b).

At the time of the coring operation (May 2001), maximum lake water depth was $6 \mathrm{~m}$. Water transparency was limited, while Löffler (1978) mentioned clear lake waters according to a Secchi disk reading. The outlet was active with an estimated flow rate of a few litres per second (Fig. 3c). The lake waters were fresh, circum neutral, roughly calcium-bicarbonate dominated with a low mean Electrical Conductivity (EC) of about $58 \mu \mathrm{s} \mathrm{cm}^{-1}$ (Fig. 2; Table 
1a, b). Except a slightly mineralized water from the swamp adjacent to the lake (sample 6), there was no evidence for a chemical variation along the flow path from the southern shore to the lake outlet to the north. Some stable isotope data was obtained on the collected samples. The value obtained on the inflow stream water sample (sample $5 ; \delta^{18} \mathrm{O}=-2.2 \%$ vs. SMOW) (Fig. 2b; Table 1c) is similar to the modern water of the lakes lying on the rift floor, and to the mean annual rainfall isotope contents recorded from the meteorological stations in Awasa and Addis Ababa (-2\%o vs. SMOW) (WMO/IAEA/GNIP Network, 2001) (Fig. 1b, c). Thus, no significant shift in precipitation characters is observed between highlands and lowlands (i.e. the central Ethiopian Plateau and the Main Ethiopian Rift). This indicates the absence of or a very low altitude effect in relation with the air mass trajectories over East Africa, as it is observed in many places in Ethiopia (Kedebe, 2004).

\section{Analytical techniques}

The Garba Guracha-I core (GG-I; $15.82 \mathrm{~m}$ long) was collected at $06^{\circ} 52.679^{\prime} \mathrm{N}$ and $39^{\circ} 51.691^{\prime} \mathrm{E}$ in the central part of Lake Garba Guracha using a Livingstone piston corer operated from a small raft anchored at $6 \mathrm{~m}$ water depth (Fig. 2b). Coring equipment was transported to the site by mules and donkeys. The coring site was selected as far as possible from clastic deposits identified along the southern, eastern and western shores. As a consequence of difficult weather conditions, only a single core was retrieved in 1-m sections. The coring operation was stopped at the depth of $\sim 16 \mathrm{~m}$ without reaching the bedrock, because of difficulty in retrieving the corer at such depths.

The core lithostratigraphy was described at the UMR 6538 CNRS/UBO, European Institute of Marine Studies in Plouzané, France. In a few core sections, reworked sediment (resulting from corer driving in) was removed from the core top. Samples were taken at $10 \mathrm{~cm}$ intervals. Microscopic lithofacies observations, grain-size determination and semi-quantification of specific lithoclastic and bioclastic fractions were conducted on these samples after sieving on a $100 \mu \mathrm{m}$ mesh. Whole-core volume magnetic susceptibility was measured using a Bartington Instruments MS2 meter with a MS2C sensor at $2 \mathrm{~cm}$ intervals. Geochemical analysis (major and trace elements) was conducted on sediment of the lower half of the core as well as on the trachytic tuff that forms the cirque base (Fig. 2b) using inductively coupled plasma-atomic emission spectroscopy (ICP-AES) at UMR 6538 CNRS/UBO.

The study of organic matter was conducted at the Earth Sciences Institute of Orléans (France) using Rock-Eval pyrolysis (Vinci-Technologies, Rueil-Malmaison, France). Samples were taken every $20 \mathrm{~cm}$. Between 50 and $100 \mathrm{mg}$ of dried sediments was used for analysis using a model 6_(RE6) device. The analysis was carried out in standard conditions for immature organic matter containing materials (i.e. starting at $200^{\circ} \mathrm{C}$ ). Rock-Eval parameters were described by (Espitalié et al., 1985a), (Espitalié et al., 1985b) and (Espitalié et al., 1986). Specific parameters provided by the new RE6 device are presented in Lafargue et al. (1998). The Rock-Eval parameters used for this study are the following ones: (i) Total Organic Carbon (TOC, \%) accounts for the quantity of organic matter present in the sediment; (ii) Hydrogen Index (HI, in $\mathrm{mg} \mathrm{HC} \mathrm{g}^{-1} \mathrm{TOC}$ ) is the amount of hydrocarbonaceous (HC) products released during pyrolysis (integrated from the $\mathrm{S} 2$ peak, in $\mathrm{mg} \mathrm{HC} \mathrm{g}^{-1}$ dry sediment) normalized to TOC; (iii) Oxygen Index OI (in $\mathrm{mg} \mathrm{O}_{2} \mathrm{~g}^{-1} \mathrm{TOC}$ ), which is related to the oxygen content of the organic matter (OM). It is calculated from the amounts of $\mathrm{CO}(\mathrm{S} 3 \mathrm{CO})$ and $\mathrm{CO}_{2}\left(\mathrm{~S} \mathrm{CO}_{2}\right)$ released during pyrolysis, normalized to TOC. Counting of the green alga Botryococcus braunii was performed along with pollen counting on the same slide and following similar lines (Umer et al., 2007). Concentration was calculated using known 
numbers of exotic pollen markers put in a known volume of pollen sample residue and a known volume of sub-sample mounted on a slide.

The radiocarbon chronology of the GG-I core is based on 11 accelerator mass spectrometry (AMS) dates performed on Total Organic Matter (TOM), since the sediments selected for dating are free of biogenic carbonates and identifiable plant remains. Samples from lithologic zones characterized by coarse deposits have been eliminated as much as possible. The samples were taken directly during the core opening, stored in cold room, and were subjected to the standard laboratory chemical protocol for AMS analyses, i.e. acid-alkali-acid treatment. AMS- ${ }^{14} \mathrm{C}$ and associated ${ }^{13} \mathrm{C}$ analyses were conducted on aliquots prepared according to the AMS protocol: burning at $860{ }^{\circ} \mathrm{C}$ for 30 min under vacuum, in the presence of a mixing of copper (II)—oxide/copper (III) — oxide and silver thread

The $\mathrm{CO}_{2}$ gas obtained was graphitized on powdered iron with hydrogen at $650{ }^{\circ} \mathrm{C}$ for $100 \mathrm{~min}$, and graphite was compressed in analytical plots. Graphite sources were prepared in the Laboratory of Hydrology and Isotope Geochemistry at the University of Orsay. Counting was performed with the accelerator mass spectrometer of the ARTEMIS facility, Gif-surYvette, France, to the exception of one sample that was analysed at Beta Analytic Inc., Miami (USA). Analytical uncertainties, including laboratory errors, are $\pm 0.1 \%$ for $\delta^{13} \mathrm{C}$ and between 0.5 and 0.8 pMC (percentage of Modern Carbon) for ${ }^{14} \mathrm{C}$ activity. Radiocarbon ages were converted to calendar ages using CALIB 5.0.2html (Stuiver and Reimer, 1993).

\section{Results}

\subsection{Lithostratigraphy}

The GG-I core reveals a continuous accumulation of fine-grained clastic sediment with interbedded layers of coarse to medium clastics in the lower half of the core, then organic muds up to the core top. The sediment succession is divided into six lithostratigraphic units as follows (LU-1 to -6 , from base to top) (Fig. $4 \mathrm{a}-\mathrm{g}$ ):

LU-1: 1582-1425 cm: Beige-green homogeneous mud with a few mm-thick silty laminae and one 4-cm-thick silty layer between 1512 and $1544 \mathrm{~cm}$. No lithoclasts characterize the $>100 \mu \mathrm{m}$ fraction with the exception of the silty laminae. The bioclastic part of the $>100 \mu \mathrm{m}$ fraction is poor, with few diatoms, and abundant ligneous and chitinous debris at the base of the core (Fig. 4e, f).

LU-2: $1425-1350 \mathrm{~cm}$ : graded coarse sand and granule bed up to $20 \mathrm{~cm}$ thick, separated at $1400 \mathrm{~cm}$ by a minor unconformity from two massive or graded fine sand beds $10-20 \mathrm{~cm}$ thick interbedded within a beige-green homogeneous mud. The $>100 \mu \mathrm{m}$ lithoclastic fraction is represented by sub-rounded to angular rock debris (3-15 $\mathrm{mm}$ in size) and well preserved feldspar (sanidine) crystals (Fig. 4c, d).

LU-3: 1350-843 cm: white grey to beige homogeneous mud with $\mathrm{mm}$ - to $\mathrm{cm}$-thick beige laminae, more frequent on the upper two-third of this interval, and 2-cm-thick gravelly sand layers, bounded at the base and top by minor discontinuities. Lithoclasts in these coarse layers are essentially angular to sub-rounded rock grains (1-5 $\mathrm{mm}$ in size) and few sanidine crystals (Fig. 4c, d). The bioclastic fraction is represented by rare to abundant small ligneous and chitinous debris (Fig. 4c, f), and few diatoms. 
LU-4: 843-408 cm: black grey homogeneous organic-rich mud. Abundant, mostly pinnate, diatoms. Poor $>100 \mu \mathrm{m}$ lithoclastic fraction (only few feldspar grains). Few ligneous fragments and abundant chitinous debris (Fig. 4c, f).

LU-5: 408-207 cm: dark grey homogeneous organic-rich mud with a discrete root layer between 215 and $212 \mathrm{~cm}$. Very poor $>100 \mu \mathrm{m}$ lithoclastic fraction (few feldspar grains). Abundant, mostly pinnate diatoms, and chitinous debris (Fig. 4f).

LU-6: 207-0 cm: dark-green homogeneous organic-rich mud. Poor or no $>100 \mu \mathrm{m}$ lithoclastic fraction. Abundant chitinous debris (Fig. 4f).

Four tephra layers 3-15 mm thick have been identified at core depth of 1.21, 3.40, 5.87 and $13.30 \mathrm{~m}$, respectively (Fig. 4a).

\subsection{Sediment geochemistry}

Major and trace elements analyses were conducted on bulk sediment sampled at various depths in the lower half (between 1582 and $843 \mathrm{~cm}$; LU-1 to -3) of the GG-I core (Fig. 4a). Similar analyses were conducted on two samples of the trachytic tuff forming the cirque base (Fig. 2b). Observed in thin section, this trachytic tuff shows a yellow beige glass shard-rich matrix including numerous feldspar grains, mainly sanidine, and ferrous oxides. Debris of glass shard-rich matrix and sanidine crystals form almost all the $>100 \mu \mathrm{m}$ lithoclastic fraction in the core sediment. This similarity in petrographical composition suggests that the sediment originates from direct erosion of the trachytic tuff. This is confirmed by geochemical analyses, particularly by trace elements such as $\mathrm{Zr}, \mathrm{Nb}$ and La that are present in very similar quantities in both the trachytic tuff and core sediment (Table 2). The classifications of Winchester and Floyd (1977) show that the sediment and trachytic tuff samples fall in the designated field for trachytes (Fig. 5).

Slightly higher quantities of trace elements such as V, Cr, Co, Ni (Table 2) are observed in the sediment with respect to the quantities of the same elements observed in the trachytic tuff. $\mathrm{V}$, $\mathrm{Cr}, \mathrm{Co}$ and $\mathrm{Ni}$ are compatible elements during igneous fractionation processes and are generally depleted in felsic rocks and enriched in mafic-ultramafic rocks. They are particularly characteristic of basaltic rocks as demonstrated by geochemical analyses conducted on the Ethiopian flood basalts (Hart et al., 1989). In addition, the Y/Ni ratio in the sediment samples is lower than for the trachytic tuff samples (Table 2). This Y/Ni ratio is lower in mafic igneous rocks $(<1)$ than in felsic igneous rocks $(>10)$. This all points to a basalt contribution to the sediment in addition to the main trachytic contribution. Variations of $\mathrm{SiO}_{2}$ content between the trachytic tuff and the core sediment (higher values in the sediment by 10 $15 \%$ ) can be attributed to a minor contribution of basalt and most probably to the presence of biogenic silica, in the form of diatom frustules in the sediment.

\subsection{Magnetic susceptibility}

The magnetic susceptibility curve (Fig. 4b) shows high values for the clastic sediments of the lower half of the core $(1582-800 \mathrm{~cm})$, and lower values for the overlying organic sediments $(800-0 \mathrm{~cm})$. Within the lower half, magnetic susceptibility values display a decreasing trend with three well defined peaks of maximum values centred around 1420-1360 cm (maximum $=35 \times 10^{-5}$ SI units), $1130-1095 \mathrm{~cm}$ (maximum $=18 \times 10^{-5}$ SI units) and $990-920 \mathrm{~cm}$ (maximum $=11 \times 10^{-5} \mathrm{SI}$ units). The magnetic susceptibility falls to very low values $(-0.4$ to 
$4.1 \times 10^{-5}$ SI units) in the uppermost section of the core reflecting the disappearance of detrital input in the basin. Comparison of magnetic characteristics between the clastic sediment in the lower half of the core and the trachytic tuff forming the basin floor shows that the sediment has a stronger magnetism than the trachytic tuff. This can be explained by a possible contribution of alteration products (clays?) issued from the basalts surrounding the cirque mixed with material of trachytic origin. Decrease in magnetic susceptibility signal may result from stronger input of trachyte-type clastics.

\subsection{Organic content}

The fluctuations of TOC and hydrogen index (HI) with depth allow dividing the series into five organic units, from base to top (OU-1 to -5 ) (Fig. 6 and Fig. 7):

OU-1: from the base of the core to $1350 \mathrm{~cm}$, TOC contents and HI values are very low and low, respectively (TOC $\leq 0.2 \%$; $\mathrm{HI} \leq 150 \mathrm{mg}$ hydrocarbon $(\mathrm{HC}) \mathrm{g}^{-1} \mathrm{TOC}$ );

OU-2: 1350 to $850 \mathrm{~cm}$ : TOC contents slightly increase. The corresponding HI values remain rather low ( $\left.<200 \mathrm{mg} \mathrm{HC} \mathrm{g}^{-1} \mathrm{TOC}\right)$ but slightly higher than in the previous interval;

OU-3: 850 to $677 \mathrm{~cm}$ : both TOC and HI values increase sharply. After having reached maximum values of about $10 \%$ and $600 \mathrm{mg} \mathrm{HC} \mathrm{g}^{-1} \mathrm{TOC}$, respectively, both TOC and HI decrease slightly to reach values of $6.5 \%$ and $450 \mathrm{mg} \mathrm{HC} \mathrm{g}^{-1} \mathrm{TOC}$, respectively, at $677 \mathrm{~cm}$ depth;

OU-4: 677 to $328 \mathrm{~cm}$ : both TOC and HI parameters record another sharp increase. Maximum values of $17.1 \%$ and $740 \mathrm{mg} \mathrm{HC} \mathrm{g}^{-1}$ TOC, respectively, are first reached at $612 \mathrm{~cm}$ depth. Then, both these parameters decrease to $9.8 \%$ and $488 \mathrm{mg} \mathrm{HC} \mathrm{g}^{-1} \mathrm{TOC}$ before rising to another maximum at $408 \mathrm{~cm}$, with similar values than those reached below. Then, the values of both these parameters fall rapidly again down to $328 \mathrm{~cm}$ depth where they reach $6.6 \%$ and $410 \mathrm{mg} \mathrm{HC} \mathrm{g}^{-1}$ TOC, respectively;

OU-5: $328 \mathrm{~cm}$ up to the core top: TOC and HI values fluctuate around values of $10 \%$ and 450-500 $\mathrm{mg} \mathrm{HC} \mathrm{g}^{-1} \mathrm{TOC}$, respectively.

Results of B. braunii counts along the core (Fig. 6) globally follow TOC variations, with very low values between $800-850 \mathrm{~cm}$ and $300-350 \mathrm{~cm}$, and still variable but with lower peak values in the top core section.

\subsection{Chronological control and deposition rates}

Radiocarbon dating shows that the GG-I core has recorded $\sim 16,700$ cal BP of environmental history of the Mount Bale region (Fig. 4 and Fig. 8; Table 3). A preliminary age value of $11,480 \pm 50{ }^{14} \mathrm{C}$ BP was obtained on a sample taken at $1582 \mathrm{~cm}$ depth by the Beta Analytic Inc., Miami (USA). This age does not fit with the coherent chronological succession displayed by the other measurements. This is possibly due to different laboratory procedures such as the use of different grain-size fractions and possible pollution of the sample by younger organic matter (humic acids). This sample has been ignored for the calculation of the age-model and sedimentation rates. 
A mean sedimentary rate (msr) of $0.95 \mathrm{~mm} \mathrm{a}^{-1}$ is calculated for the overall core. Four units (SRU-1 to -4) can be distinguished from base to top, according to the variations of the sedimentation rate (Fig. 8):

SRU-1: from 1582 to $1380 \mathrm{~cm}(16,700-13,480 \mathrm{cal} \mathrm{BP})$, sediment accumulated at a mean rate of $0.71 \mathrm{~mm} \mathrm{a}^{-1}$.

SRU-2: from 1380 to $820 \mathrm{~cm}(13,480-11,765$ cal BP), the mean sedimentation rate shows a drastic increase up to $3.28 \mathrm{~mm} \mathrm{a}^{-1}$. Within this general increase of sedimentation rate, one stage of accelerated detrital inputs can be identified with a rate value of ca $3.56 \mathrm{~mm} \mathrm{a}^{-1}$ between 13,480 and 12,900 cal BP, that increases up to $3.92 \mathrm{~mm} \mathrm{a}^{-1}$ between 12,900 and 12,600 cal BP.

SRU-3: from 820 to $328 \mathrm{~cm}(11,765-4600 \mathrm{cal} \mathrm{BP})$, the sedimentation rate decreases by a factor of almost five compared to the preceding phase $\left(0.68 \mathrm{~mm} \mathrm{a}^{-1}\right)$.

SRU-4: from $328 \mathrm{~cm}$ to the core top: this phase is marked by a very slight increase of sedimentation rate up to $0.72 \mathrm{~mm} \mathrm{a}^{-1}$.

\section{Interpretation and discussion}

Variations in grain size, sediment composition, TOC and HI values and changes in sedimentation rates registered along the GG-I core support the distinction of five main sedimentary phases (Fig. 4j):

- Phase I (from the base of the core to $1350 \mathrm{~cm}$ ): sedimentation is terrigenous with particularly well expressed coarse clastic inputs in LU-2 unit.

- Phase II (from 1350 to $1050 \mathrm{~cm}$ ): sedimentation is always terrigenous with a strong increase in the rate of sedimentation (SR value five times higher than during Phase I) (Fig. 8).

- Phase III (1050-843 cm): sedimentation is always terrigenous but shows a clear decrease in grain size and sedimentation rate. To the exception of few organic-rich levels (e.g., up to $11.5 \%$ ) at $1309 \mathrm{~cm}$ depth, phases II and III are both characterized by a uniformly low TOC background (Fig. 6).

- Phase IV (from 843 to $328 \mathrm{~cm}$ ): the clastic-dominated period is abruptly interrupted and replaced by OM-rich sedimentation;

- Phase V (from $328 \mathrm{~cm}$ to the core top) differs from Phase IV by lower OM amounts. This material is also poorer in hydrogen ( $\mathrm{HI}<500 \mathrm{mg} \mathrm{HC} \mathrm{g}^{-1} \mathrm{TOC}$ ) that can be at least partly explained by lower inputs of hydrocarbon-rich Botryococcus algae (Fig. 6). These two last phases record the post-glacial development of the Lake Garba Guracha.

Interpretation of Phases I to III must take into account the peculiar paleoenvironmental/paleoclimatic characteristics of the time period covered by the GG-I core in this region of Ethiopia. Osmaston and colleagues demonstrated that the northern slopes of the Bale Mountains have been affected by successive phases of glaciation, with the existence of a central ice cap at $4000 \mathrm{~m}$ elevation on the Sanetti Plateau during LGM while the Togona valley was glaciated down to 3400 m elevation (Osmaston and Harrison, 2005; Osmaston et 
al., 2005; Mitchell et al., 2006) (Fig. 1d). The morphology of the Lake Garba Guracha basin is typical of a glacial cirque (Evans, 1994) (Fig. 2 and Fig. 9). It relates to the presence during LGM or prior glaciation of a small glacier tongue that possibly connected downward to the main Togona valley glacier (Fig. 10a). As it is classically known for glacial cirques (Allix, 1954; Boulton, 1974; Evans, 1994; Federici and Spagnolo, 2004; Turnbull and Davies, 2006), the Garba Guracha cirque was very likely over-deepened as a consequence of both glacial erosion and soft lithology of the cirque base. This resulted in creating accommodation space (minimum observed $22 \mathrm{~m}=6 \mathrm{~m}$ water depth $+16 \mathrm{~m}$ cored sediment) available for further water and sediment accumulation (Fig. 9).

Morphological studies and pollen data from cores taken in bogs and swamps (Hamilton, 1982; Bonnefille and Hamilton, 1986; Mohammed and Bonnefille, 1998; Osmaston et al., 2005) suggested that deglacierisatio processes started at $\sim 16,700 \mathrm{yr}$ cal BP in the Bale Mountains as well as in all the Ethiopian highlands (Mount Bada and Simen Mountains), in the Rwenzori (Livingstone, 1967; Osmaston et al., 2005), and more widely throughout East Africa (Street, 1981; Osmaston et al., 2005). In the GG-I core, Phase I is dated between 16,700 and $13,400 \mathrm{cal}$ BP (1582-1350 cm core depth). Sedimentary facies at the very base of the core demonstrates that a lake was in existence in the Garba Guracha cirque at 16,700 cal BP. As the coring operation was ended without reaching the bedrock, older sediments of unknown thickness and of lacustrine or other type of facies (glaciogenic?) exist below the base of GG-I core (Fig. 9). This indicates that the northern and central parts of the Garba Guracha cirque were accommodating water and sediment input at least slightly before $16,700 \mathrm{cal} \mathrm{BP}$, confirming that glacier already retreated into the central part of the cirque (Fig. 10b).

Lithologic and geochemical analogies of the sediment in LU-1 to -3 units and the trachytic tuff forming the cirque base confirm a "monogenic" source of the sediment, issued from direct mechanical erosion of the basin floor. Nevertheless, a contribution in the form of dissolved elements or alteration products of basaltic rocks from the sidewalls of the cirque, is also indicated by the geochemical composition of the sediment (Table 2) and locally by its magnetic characteristics (Fig. 4b). Within the peculiar paleoenvironmental/paleoclimatic context of the time period illustrated by the lower half of GG-I core, sediment production in the basin can relate to two types of erosive process: (1) runoff and/or freeze-thaw processes that would have affected the whole basin, characterized by two different substrates, trachytic for the cirque base and basaltic for the sidewalls. In such a case, the main trachytic character of the core sediment is difficult to explain; nevertheless, a possible reworking of an older "single source" glaciogenic sediment generated during a prior phase of glacier occupation of the basin can also be envisaged. The presence of moraines have been suggested on the northwest side of the lake basin (Umer et al., 2007; W.A. Mitchell, pers. com. to H.F. Lamb) (Fig. 2b); (2) glacial scour of the trachytic cirque base by a glacier lobe some tens of $m$ thick, generating a "monogenic" rock flour (Sugden and John, 1988) lithologically and geochemically similar to the sediment cored.

Clastic sedimentation in an already established lacustrine environment at 16,700 cal BP, involving runoff eroding the cirque floor, its sidewalls and the plateau surrounding the Garba Guracha cirque, or reworking of an older till can be envisaged. Coarse basaltic clasts have not been identified in the $>100 \mu \mathrm{m}$ lithoclastic fraction of the core sediment. Only dissolved elements are present as shown by geochemical analyses. In addition, palynological data (Umer et al., 2007) indicate dry climatic conditions during pollen zone GG-1 (16,70013,400 cal BP) (Fig. 4i) that do not support important runoff and associated erosive process at the basin scale, even with a sparse vegetation cover. 
It is therefore suggested that water and sediment input in the cirque before $16,700 \mathrm{cal} \mathrm{BP}$ and during Phase I (16,700-13,400 cal BP) (1582-1350 cm core depth) relates to glacier recession within the cirque (Fig. 4 and Fig. 10). Glacier retreat progressively released accommodation space existing in the over-deepened part of the cirque. This process resulted first in a small "ice-contact lake" filled by meltwater streams entering at the lake surface or at the lake bottom and transporting ice-trapped fine-grained till (Fig. 10b). Silty laminations near the base of the core and normally graded sands separated by small erosional discontinuities between 1420 and $1360 \mathrm{~cm}$ core depth (Fig. 4a) suggest pulses in ice melting and meltwater input that generate density underflows eroding the underlying deposits (Smith and Ashley, 1985). Continuation of glacier retreat resulted in a "distal lake" fed by outwash streams (Fig. 10c). Parts of the stabilized basaltic screes that exist today on the sides of the cirque (Fig. 2 and Fig. 3) may represent possible remnants of rubbly lateral moraines or rock slope failures resulting from various processes during glacier retreat, such as strength decrease of the sidewalls or freeze-thaw effects (Turnbull and Davies, 2006) (Fig. 10a-d). The presence in the lake sediment of dissolved elements characteristics of basaltic rocks may relate to such freeze-thaw effects or gentle erosion/dissolution on the sidewalls of the cirque during previous stages of glaciation. The slight increase in organic matter content after 13,400 cal BP (i.e. at $1350 \mathrm{~cm}$ core depth) records the progressive development of vegetation. The decrease of magnetic susceptibility signal may also relate to a change in sediment granulometry possibly linked to the development of vegetal cover (Fig. 4 and Fig. 6).

Phase II between 13,400 and 12,500 cal BP (1350-1050 cm core depth) is characterized by high values of sedimentation rate (3.28-3.92 $\mathrm{mm} \mathrm{a}^{-1}$ ) (Fig. 8 and Fig. 10). Such values are similar to those described in distal lakes of the LGM Alpine environment and interpreted as linked to glacier recession (Brauer and Casanova, 2001; Manalt et al., 2001; Nomade, 2005). This strong increase in sediment deposition may relate to acceleration of ice melting and related meltwater/sediment discharge as a consequence of a rapid change to wetter climatic conditions as indicated by pollen data, with a sharp decrease in the abundance of Amaranthaceae/Chenopodiaceae (Umer et al., 2007) (Fig. 4 and Fig. 8). Increased plant production at the time and especially in the lake and on its borders is supported by increased proportions of Botryococcus algae and Cyperaceae, respectively (Umer et al., 2007).

Contributions from these sources and from plants growing on the watershed are consistent with Rock-Eval pyrolysis data denoting low contents of notably altered OM of terrestrial or mixed origin (ca $0.5 \%$ TOC; $\mathrm{HI}=100-150 ; \mathrm{IO}>200$ ) as well as with the rather abundant ligneous debris also found in this core section (Fig. 4e). The strong input of water and sediment into the lake during this phase may have resulted in lake outlet initiation over the rock bar at the northern end of the lake basin (Fig. 10d).

Within the general increase of sedimentation rate recorded in Phase II, the maximum value $\left(3.92 \mathrm{~mm} \mathrm{a}^{-1}\right)$ is identified between 12,940 and $12,600 \mathrm{cal}$ BP possibly reflecting a delayed effect of increased moisture on ice melting processes. At that time, low TOC values may be mostly due to dilution of the OM by the strong mineral input. A high sedimentation rate preventing the $\mathrm{OM}$ from marked diagenetic evolution and $\mathrm{HI}$ values mostly comprised between 100 and $200 \mathrm{mg} \mathrm{HC} \mathrm{g}^{-1}$ can thus be interpreted as characteristic of slightly altered debris of plants issued from the watershed and/or from macrophytes growing on the lake border. This hypothesis is sustained by the rather great abundance of plant debris and the few B. braunii algae present in the sediment (Fig. 6). A few levels with high TOC ( $>9 \%$ at 1309 and $1319 \mathrm{~cm})$ and $\mathrm{IH}$ values ( $>450 \mathrm{mg} \mathrm{HC} \mathrm{g}^{-1}$ TOC) may relate to preservation of higher plant material consequently to a fast burial coeval with coarse detrital input. In the lower part 
of this phase (1330 cm core depth; 13,310 cal BP), the deposition of 1-mm-thick tephra layer records a pyroclastic eruption from a nearby volcano in the MER (Le Turdu et al., 1999).

During Phase III (from 12,500 to 11,800 cal BP; 1050-843 cm core depth), sedimentation becomes fine-grained and laminated without a major change in lithological/geochemical characteristics. Such low-energy sedimentation indicates a decreasing influx of water and sediment and/or a remote source. This suggests that the lobe of dead ice was at that time restricted to the south end of the cirque, with outwash streams bringing smaller quantities of water and fine-grained sediment in the distal lake (Fig. 10e). As in Phase II, the TOC values remain uniformly low, relating possibly to a decrease in local vegetation in the basin (Umer et al., 2007). Nevertheless, coarse sediment input from this dead ice lobe may also have been trapped in the alluvial plain that extends the lake basin toward the south end of the cirque (Fig. 2, Fig. 3 and Fig. 10). During this phase, a return to cold and dry conditions as indicated by pollen record at 12,700-11,500 cal BP (Umer et al., 2007) possibly coeval to the Younger Dryas cold event in the northern latitudes (Goslar et al., 1995; Alley, 2000) may also have influenced the sedimentation by blocking or slowering the ice melting process.

Phase IV from 11,800 to $4500 \mathrm{cal}$ BP $(843-328 \mathrm{~cm})$ records the abrupt setting of the postglacial lake characterized by the complete disappearance of clastic input in the lake and replacement by OM-rich sedimentation (Fig. 10f), with a purely bioclastic $>100 \mu \mathrm{m}$ fraction (mainly debris of planktonic organisms, that are described as abundant in tropical high mountain lakes; Löffler, 1978), and an organic fraction characterized by high TOC and HI values (Fig. 6 and Fig. 7). The steep increase of TOC and HI denotes a rise in the autochthonous lacustrine production amplified by the simultaneous lowering of the mineral input. In this respect, the very high HI values ( $>500 \mathrm{mg} \mathrm{HC} \mathrm{g}^{-1} \mathrm{TOC}$ ) frequently found between 850 and $328 \mathrm{~cm}$ denote an important contribution of hydrogen-rich organisms such as B. braunii green algae (Fig. 6 and Fig. 7) combined with a high OM preservation under a permanent water body. These algae moreover indicate that lake water was oligohaline. Variations of TOC and IH are recorded with minimum values at $677 \mathrm{~cm}$ depth, and two maxima at 612 and $408 \mathrm{~cm}$ (Fig. 6). Such variations in the quantity of OM and its quality are certainly mostly due to fluctuations in lacustrine autochthonous production as illustrated by the important variations in B. braunii counts in the upper core section. Dense blooms of $B$. braunii are known to occur after heavy rains in association with increased availability of dissolved phosphorus. They can relate seasonal variations in water balance, $\mathrm{pH}$ and nutrient supply Huang et al., 1999 (Fig. 6). At 587 and $340 \mathrm{~cm}$ core depth ( 8020 and $\sim 4720$ cal BP), two thin tephra layers indicate again explosive eruptions possibly from volcanoes in the MER.

Phase V from 4500 cal BP (328 cm up to the core top) (Fig. 10f) is characterized by a rapid fall of $\mathrm{HI}$ and TOC values that fluctuate around $10 \%$ and $450-500 \mathrm{mg} \mathrm{HC} \mathrm{g}^{-1} \mathrm{TOC}$, respectively, associated to a relative fall in B. braunii concentrations (Fig. 6). These rather low values reflect the decrease in lacustrine production and increased dryness after 4500 cal BP, that fit the general pattern of the well known Late Holocene aridity throughout northern Africa and related lake level fall of the Rift Valley lakes (Gasse, 2000; Marchant and Hooghiemstra, 2004).

\section{Conclusions}

The Garba Guracha-I core is the longest and best dated sedimentary record of environmental change from above $3000 \mathrm{~m}$ altitude in Africa. It provides at three different scales of space new insight into (a) the climatic history of northeastern Africa during the last 16,700 years; 
(b) the vegetational history and biodiversity of the ethiopian highlands (Umer et al., 2007); and (c) the deglaciation mechanisms at the scale of the northern slopes of the Bale Mountains. The most recent results from glaciological studies in the Bale Mountains of Ethiopia have shown that valleys were probably occupied during LGM by glaciers and that highest summits were covered by ice caps (Messerli et al., 1977; Umer et al., 2003; Osmaston and Harrison, 2005; Osmaston et al., 2005). The Garba Guracha cirque which has been studied here is known as having been ice-filled (Osmaston et al., 2005) and over-deepened by glacier erosion. These results have been deduced from geomorphological type data. The sedimentological data provided by the GG-I core clearly highlights the chronology of the deglaciation on the northern slopes of the Bale Mountains. The GG-I core also provides a unique record of the sedimentary processes linked to the progressive retreat of a high-altitude glacier in the African tropics. One of the major results is that the recession of the glacier filling the Garba Guracha cirque was already underway at $\sim 16,700$ cal BP $\left(13,950{ }^{14} \mathrm{C}\right.$ yr BP $)$. Pollen data from a site located at $3000 \mathrm{~m}$ elevation on the same mountains suggested the beginning of the deglaciation to be initiated at about the same time (Mohammed and Bonnefille, 1998).

This is the oldest minimum age proposed for deglaciation in East Africa, compared to the other minimum ages presented for Mount Elgon $\left(11,000{ }^{14} \mathrm{C}\right.$ yr BP; Hamilton and Perrott, 1979; Hamilton, 1982), in the Aberdare Mountains (12,200 ${ }^{14} \mathrm{C} \mathrm{yr}$ BP; Perrott, 1982), both in the Kenya Rift, and in the Danka Valley of the Bale Mountains where a minimum age of 7500 ${ }^{14} \mathrm{C}$ yr BP is cited (Hamilton, 1982; Bonnefille and Hamilton, 1986). It is also proposed that a dead ice lobe could have remained for a few thousands of years (from 16,700 to $\sim 12,500$ 11,800 cal BP) (e.g., Cohen, 2003) on the colder shaded north-facing slope of the Garba Guracha cirque despite the major change in global climate. During this period, meltwater and associated till discharge from this retreating ice lobe progressively infilled available accommodation space in the over-deepened part of the cirque and contributed to create a glacially fed lake. However, older lake sediments could be present below the base of the core, indicating earlier deglaciation of the cirque. This is also supported by pollen record from the GG-I core that demonstrates dry conditions during the Late Pleistocene, that may have favoured early deglaciation (Umer et al., 2007).

From $\sim 11,800$ cal BP upward, an almost purely organic-rich sedimentation witnesses the transition from the glacier-fed lake to an open lacustrine domain characterized by the disappearance of glacier detrital input and occurrence of a high organic productivity, a marker of increased rainfall, rise in temperature and increase in woody vegetation cover in the lake catchment. Originating from and supplied by glacier meltwater during the whole deglaciation, the Lake Garba Guracha remained fresh throughout the Holocene, being fed only by meteoric water via both direct precipitation on the lake surface and rapidly-transferred water through the highly fractured basaltic plateau. During the early to mid-Holocene, the Lake Garba Guracha record shows a clear stability of chemical, environmental and hydrological balances due to water discharge over the rock bar that bounds the basin to the NNE. Such stability is in opposition with the quick-alternating high- and low-lake level intervals in the Ziway-Shala lake system in the Main Ethiopian Rift during the same period (Le Turdu et al., 1999; Chalié and Gasse, 2002). In the same way, no vegetational response at Garba Guracha relates to these intervals of aridity (Umer et al., 2007).

A major limnological event is registered at $\sim 4500 \mathrm{cal}$ BP in the form of an abrupt decrease in lake productivity interpreted as a response to an increase in dryness. This climatic change to Late Holocene aridity, well known throughout northern Africa (Marchant and Hooghiemstra, 
2004), is marked on the northern slopes of the Bale Mountains by the expansion of dry Afromontane forest and the disappearance of Erica forest from the lake catchment (Umer et al., 2007). From 4500 cal BP, slight variations of TOC values may suggest short-term fluctuations in climate dryness as it is recorded in the rift lakes that show alternating regressive and transgressive phases within a general phase of retreat for the mid-Late Holocene (Mohammed and Bonnefille, 1991; Bonnefille et al., 1986; Le Turdu et al., 1999).

This study of the last 17,000 years history of the high altitude Lake Garba Guracha illustrates the complex interactions between global (climate) and local (glacier dynamics vs. local climate) processes in the setting and evolution of the very sensitive environment of the Ethiopian highlands.

\section{Acknowledgements}

This research was conducted as part of the ERICA (Environmental Research for Intertropical Climate in Africa) Project initiated by R. Bonnefille. The coring operation (MUM, DH, JJT) and laboratory analyses were funded by the INSU-CNRS "Corne de l'Afrique" Program. The Earth Sciences Department of the Addis Ababa University, the Cultural and Scientific Service of the French Embassy in Ethiopia and the Bale Mountains National Park provided facilities and field assistance. Special thanks are due to INSU-CNRS for having supported MUM as Research Associate at UMR CNRS/UBO 6538 "Domaines Océaniques", Institut Universitaire Européen de la Mer (IUEM), Plouzané, France. The authors would like to thank Welde Selassie Gebrehiwot and Hailu Dibabe from Addis Ababa University and the guide Hajii from Bale Mountains National Park for their invaluable help when coring in the field. Special acknowledgements are also due to J. Cotten for geochemical analyses, D. Williamson for discussion on magnetic susceptibility data, M. Benoit and P. Huntsman-Mapila for interpretation of geochemical data and the reviewers for their constructive comments.

\section{References}

Alessio et al., 1996 M. Alessio, L. Allegri, G. Belluomini, M. Benvenuti, M. Cerasoli, S. Improta, L. Manfra, M. Sagri and D. Ventra, Le oscillazioni tardo-quaternarie del Lago Shala (Rift Etiopico): analisi dell'evoluzione ambientale dall'integrazione di evidenze morfologiche, sedimentarie e cronologiche, Il Quaternario 9 (1996), pp. 387-392.

Alley, 2000 R.B. Alley, The younger dryas cold interval as viewed from central Greenland, Quaternary Science Reviews 19 (2000), pp. 213-226.

Allix, 1954 Allix, A., 1954. L'action morphologique de la glace et celle des coulées de neige (sillons d'avalanches), Mél. Bénévent, Gap, pp. 11-17.

Benvenuti et al., 2002 M. Benvenuti, S. Carnicelli, G. Belluomini, N. Dainelli, S. Di Grazia, G.A. Ferrari, C. Iasio, M. Sagri, D. Ventra, A. Balemwald and K. Seifu, The Ziway-Shala lake basin (main Ethiopian rift, Ethiopia): a revision of basin evolution with special reference to the late quaternary, Journal of African Earth Sciences 35 (2002), pp. 247-269. 
Bonnefille and Hamilton, 1986 C. Bonnefille and A.C. Hamilton, Quaternary and late Tertiary history of Ethiopian vegetation, Acta Universitatis Uppsaliensis Symbolae Botanicae Uppsalienses 26 (2) (1986), pp. 48-63.

Bonnefille and Mohammed, 1994 R. Bonnefille and U. Mohammed, Pollen-inferred climatic fluctuations in Ethiopia during the last 3000 years, Palaeogeography, Palaeoclimatology, Palaeoecology 109 (1994), pp. 331-343.

Bonnefille et al., 1986 Bonnefille, R., Robert, C., Delibrias, G., Elenga, C., Herbin, J.P., Lézine, A.M., Périnet, G., Tiercelin, J.J., 1986. Palaeoenvironment of Lake Abijata, Ethiopia, during the past 2000 years. In: Frostick, L.E., Reid, I., Renaut, R.W., Tiercelin, J.J. (Eds.), Sedimentation in African Rifts, Geological Society of London, Special Publication, vol. 25, pp. 253-265.

Boulton, 1974 G.S. Boulton, Processes and patterns of glacial erosion. In: D.R. Coates, Editor, Glacial Geomorphology, George Allen \& Unwin, London (1974), pp. 41-87.

Brauer and Casanova, 2001 A. Brauer and J. Casanova, Chronology and depositional processes of the laminated sediment record from Lac d'Annecy, French Alps, Journal of Paleolimnology 25 (2001), pp. 163-177.

Chalié and Gasse, 2002 Chalié, F., Gasse, F., 2002. Late Glacial-Holocene diatom record of water chemistry and lake level change from the tropical East African Rift Lake Abiyata (Ethiopia). In: Tiercelin, J.-J. (Ed.), Lake Sediments: archives of Active Tectonics and Climate Changes. Palaeogeography, Palaeoclimatology, Palaeoecology 187, 259-283.

Cohen, 2003 A.S. Cohen, Paleolimnology. The History and Evolution of Lake Systems, Oxford University Press (2003) 500pp.

Espitalié et al., 1985a J. Espitalié, G. Deroo and F. Marquis, La pyrolyse Rock-Eval et ses applications; première partie, Revue de l'Institut Français du Pétrole 40 (1985), pp. 563-579.

Espitalié et al., 1985b J. Espitalié, G. Deroo and F. Marquis, La pyrolyse Rock-Eval et ses applications; deuxième partie, Revue de l'Institut Français du Pétrole 40 (1985), pp. 755784.

Espitalié et al., 1986 J. Espitalié, G. Deroo and F. Marquis, La pyrolyse Rock-Eval et ses applications; troisième partie, Revue de l'Institut Français du Pétrole 41 (1986), pp. 73-78.

Ethiopia map, 1999a Ethiopia map, 1999a. 1:1,000,000, Awasa, Series EMA 5, Sheet NB-37, first ed. Ethiopian Mapping Authority.

Ethiopia map, 1999b Ethiopia map, 1999b. 1:250,000, Dodola, Series EMA 3, Sheet NB-377, second ed. Ethiopian Mapping Authority.

Ethiopia map, 2000 Ethiopia map, 2000. 1:50,000, Batu, Series ETH 4, Sheet 0639 B2, first ed. Ethiopian Mapping Authority. 
Evans, 1994 I.S. Evans, Lithological and structural effects on forms of glacial erosion: cirques and lake basins. In: D.A. Robinson and R.B.G. Williams, Editors, Rock Weathering and Landform Evolution, Wiley, London (1994).

Federici and Spagnolo, 2004 P.R. Federici and M. Spagnolo, Morphometric analysis on the size, shape and areal distribution of glacial cirques in the Maritime Alps (western FrenchItalian Alps), Geografiska Annaler 86A (2004), pp. 235-248.

Gasse, 2000 F. Gasse, Hydrological changes in the African tropics since the Last Glacial Maximum, Quaternary Science Reviews 19 (2000), pp. 189-211.

Gasse and Street, 1978 F. Gasse and F.A. Street, Late Quaternary lake-level fluctuations and environments of the northern Rift Valley and Afar region (Ethiopia and Djibouti),

Palaeogeography, Palaeoclimatology, Palaeoecology 25 (1978), pp. 145-150.

Gibert et al., 1999 E. Gibert, Y. Travi, M. Massault, T. Chernet, F. Barbecot and F. LaggounDefarge, Comparison between carbonate and organic AMS ${ }^{14} \mathrm{C}$ ages in Lake Abiyata sediments (Ethiopia): hydrochemistry and palaeoenvironmental implications, Radiocarbon 41 (3) (1999), pp. 251-266.

Gibert et al., 2002 E. Gibert, Y. Travi, M. Massault, J.-J. Tiercelin and T. Chernet, AMS ${ }^{14} \mathrm{C}$ chronology of a lacustrine sequence from Lake Langano (Ethiopia): correction and validation steps in relation with volcanism influence, and lake water and carbon balances, Radiocarbon 44 (2002), pp. 75-92.

Gillespie et al., 1983 R. Gillespie, F.A. Street-Perrott and R. Switsur, Post-glacial arid episodes in Ethiopia have implications for climate prediction, Nature 306 (1983), pp. 680683.

Gobena et al., 1996 Gobena, H., Belayneh, M., Kebede, T., Tesfaye, S., Abraham, A., 1996. Geology of the Dodola area. Memoir 10, Geological Survey of Ethiopia, Addis Ababa.

Gobena et al., 1998 Gobena, H., Belayneh, M., Kebede, T., Tesfaye, S., 1998. Map Sheet NB37-7 Dodola, Scale 1/250,000. Geological Survey of Ethiopia, Abbis Ababa.

Goslar et al., 1995 T. Goslar, M. Arnold and M.F. Pazdur, The Younger Dryas Cold eventwas it synchronous over the North Atlantic region?, Radiocarbon 37 (1995), pp. 1-8.

Grab, 2002 S. Grab, Glacial and periglacial phenomena in Ethiopia: a review, Permafrost and Periglacial Processes 13 (1) (2002), pp. 71-76.

Griffiths, 1972 J.F. Griffiths, Climates of Africa, World Survey of Climatology Vol. 10, Elsevier, Amsterdam (1972).

Grove and Goudie, 1971 A.T. Grove and A.S. Goudie, Late Quaternary lake levels in the Rift Valley of southern Ethiopia and elsewhere in tropical Africa, Nature 234 (1971), pp. 403405.

Hamilton, 1982 A.C. Hamilton, Environmental history of East Africa: a study of the Quaternary, Academic Press, London (1982). 
Hamilton and Perrott, 1979 A.C. Hamilton and R.A. Perrott, Date of deglacierisation of Mount Elgon, Nature 273 (5657) (1979), p. 49.

Hart et al., 1989 W.K. Hart, G. WoldeGabriel, R.C. Walter and S.A. Mertzman, Basaltic volcanism in Ethiopia: constraints on continental rifting and mantle interactions, Journal of Geophysical Research 94 (B6) (1989), pp. 7731-7748.

Huang et al., 1999 Y. Huang, F.A. Street-Perrott, R.A. Perrott, P. Metzger and G. Eglinton, Glacial-interglacial environmental changes inferred from molecular and compound-specific $\delta^{13} \mathrm{C}$ analyses of sediments from Sacred Lake, Mt. Kenya, Geochimica et Cosmochimica Acta 63 (9) (1999), pp. 1383-1404.

Kaser and Osmaston, 2002 G. Kaser and H.A. Osmaston, Tropical Glaciers (with Map of Glaciers and Glaciations of the Rwenzori Mountains, Uganda), Cambridge University Press, Cambridge (2002) 207pp.

Kedebe, 2004 Kedebe, S., 2004. Environmental isotopes and geochemistry in investigating groundwater and lake hydrology: cases from the Blue Nile Basin and Ethiopian Rift (Ethiopia). Thèse de Doctorat, Université d'Avignon, France, 176pp.

Lafargue et al., 1998 E. Lafargue, F. Marquis and D. Pillot, Rock-Eval 6 applications in hydrocarbon exploration, production and soil contamination studies, Revue de l' Institut Français du Pétrole 53 (1998), pp. 421-437.

Lamb, 2001 H.F. Lamb, Holocene climatic change and vegetation response inferred from the sediments of Ethiopian crater lakes, Proceedings of the Royal Irish Academy 101 (B(1-2)) (2001), pp. 35-46.

Lamb et al., 2000 A.L. Lamb, M.J. Leng, H.F. Lamb and M. Mohammed Umer, A 9000-year oxygen and carbon isotope record of hydrological change in a small Ethiopian crater lake, Holocene 10 (2000), pp. 167-177.

Lamb et al., 2004 A.L. Lamb, M.J. Leng, M. Mohammed Umer and H.F. Lamb, Holocene climate and vegetation change in the Main Ethiopian Rift Valley, inferred from the composition $\left(\mathrm{C} / \mathrm{N} \& \delta^{13} \mathrm{C}\right.$ ) of lacustrine organic matter, Quaternary Science Reviews $\mathbf{2 3}$ (2004), pp. 881-888.

Legesse Dagnachew et al., 2002 Legesse Dagnachew, Gasse, F., Radakovitch, O., ValletCoulomb, C., Bonnefille, R., Verschuren, D., Gibert, E., Barker, P., 2002. Environmental changes in a tropical lake (Lake Abiyata, Ethiopia) during recent centuries. In: Tiercelin, J.-J. (Ed.) Lake sediments: Archives of Active Tectonics and Climate Changes. Palaeogeography, Palaeoclimatology, Palaeoecology 187, 233-258.

Le Turdu et al., 1999 C. Le Turdu, J.-J. Tiercelin, E. Gibert, Y. Travi, K.E. Lezzar, J.-P. Richert, M. Massault, F. Gasse, R. Bonnefille, M. Decobert, B. Gensous, V. Jeudy, T. Endale, M. Umer, K. Martens, B. Atnafu, T. Chernet, D. Williamson and M. Taïeb, The Ziway-Shala lake basin system, Main Ethiopian Rift: Influence of volcanism, tectonics and climatic forcing on basin formation and sedimentation, Palaeogeography, Palaeoclimatology, Palaeoecology 150 (1999), pp. 135-177. 
Lézine and Bonnefille, 1982 A.M. Lézine and R. Bonnefille, Diagramme pollinique Holocène d'un sondage du lac Abiyata (Ethiopie, 742’N), Pollen et Spores 24 (1982), pp. 463-480.

Livingstone, 1967 D.A. Livingstone, Postglacial vegetation of the Ruwenzori Mountains in Equatorial Africa, Ecological Monographs 37 (1967), pp. 25-52.

Löffler, 1978 H. Löffler, Limnology and paleolimnological data on the Bale Mountain Lakes, Verth, International Verein. Limnology, Stuttgart (Deutschland) 20 (1978), pp. 1131-1138.

Manalt et al., 2001 F. Manalt, C. Beck, J.R. Disnar, J.-F. Deconinck and P. Recourt, Evolution of clay mineral assemblages and organic matter in the late glacial-holocene sedimentary infill of lake Annecy (Northwestern Alps): paleoenvironmental implications, Journal of Paleolimnology 25 (2001), pp. 179-192.

Marchant and Hooghiemstra, 2004 R. Marchant and H. Hooghiemstra, Rapid environmental change in African and South American tropics around 4000 years before present: a review, Earth-Science Reviews 66 (2004), pp. 217-260.

Messerli et al., 1977 Messerli, B., Hurni, H., Kienholz, H., Winiger, M., 1977. Bale Mountains, the largest Pleistocene mountain glacier system of Ethiopia. INQUA abstracts, Birmingham, p. 300.

Miehe and Miehe, 1994 Miehe, S., Miehe, G., 1994. Ericaceous Forests and Heatlands in the Bale Mountains of south Ethiopia. Ecology and Man's Impact. T. Warnke Verlag, Hamburg.

Mitchell et al., 2006 W.A. Mitchell, H.A. Osmaston and J.A.N. Osmaston, Quaternary glaciation of the Bale Mountains, Ethiopia, Geophysical Research Abstracts 8 (2006), p. 04767.

Mohammed, 1992 Mohammed, M.U., 1992. Paléoenvironnement et paléoclimatologie des derniers millénaires en Ethiopie. Contribution palynologique. Thèse de Doctorat, Université d'Aix-Marseille III, 219 pp.

Mohammed and Bonnefille, 1991 M.U. Mohammed and R. Bonnefille, The recent history of vegetation and climate around Lake Langano (Ethiopia), Palaeoecology of Africa 22 (1991), pp. 267-280.

Mohammed and Bonnefille, 1998 M.U. Mohammed and Bonnefille, A late Glacial/late Holocene pollen record from a highland peat at Tamsaa, Bale Mountains, South Ethiopia, Global and Planetary Change 16-17 (1998), pp. 121-129.

Mohr, 1971 P.A. Mohr, The Geology of Ethiopia, University Press, Addis Ababa (1971).

Nicholson, 1996 Nicholson, S.E., 1996. A review of climate dynamics and climate variability in Eastern Africa. In: Johnson, T.C., Odada, E. (Eds.), The Limnology, Climatology and Paleoclimatology of the East African Lakes, The International Decade for the East African Lakes (IDEAL). Gordon and Breach Publishers, pp. 25-56. 
Nomade, 2005 Nomade, J., 2005. Chronologie et sédimentologie du remplissage du lac d'Annecy depuis le Tardiglaciaire:Implications paléoclimatologiques et paléohydrologiques. Thèse de Doctorat, Université Joseph Fourier, Grenoble I, 181pp.

Osmaston and Harrison, 2005 H.A. Osmaston and S.P. Harrison, The Late Quaternary glaciation of Africa: a regional synthesis, Quaternary International 138-139 (2005), pp. 32 54.

Osmaston et al., 2005 H.A. Osmaston, W.A. Mitchell and J.A.N. Osmaston, Quaternary glaciation of the Bale Mountains, Ethiopia, Journal of Quaternary Science 20 (2005), pp. 593-606.

Perrott, 1982 Perrott, R.A., 1982. A postglacial pollen record from Mt. Satima, Aberdare Range, Kenya. American Quaternary Association Conference, vol. 7. Program and Abstracts, p. 153.

Shanahan and Zreda, 2000 T.M. Shanahan and M. Zreda, Chronology of quaternary glaciations in East Africa, Earth and Planetary Science Letters 177 (2000), pp. 23-42.

Smith and Ashley, 1985 Smith, N.D., Ashley, G.M., 1985. Proglacial fluvial environment. In: Ashley, G.M., Shaw, J., Smith, N.D. (Eds.), Glacial Sedimentary Environments, Soc. Econ. Paleont. Miner., Short Course, vol. 16. Tulsa, pp. 135-216.

Street, 1979 Street, F.A., 1979. Late Quaternary lakes in the Ziway-Shala Basin, Southern Ethiopia. Ph.D. Thesis, University of Cambridge.

Street, 1981 Street, F.A., 1981. Chronology of Late Pleistocene and Holocene lake-level fluctuations, Ziway-Shala Basin, Ethiopia. In: Leakey, R.E., Ogot, B.A. (Eds.), Proceedings of the Eighth Panafrican Congress of Prehistory and Quaternary Studies, 1977, September 510, Nairobi, Kenya, pp. 143-146.

Stuiver and Reimer, 1993 Stuiver, M., Reimer, P.J., 1993. Extended ${ }^{14} \mathrm{C}$ database and revised CALIB radiocarbon calibration program. Radiocarbon 35, 215-230.

Sugden and John, 1988 D.E. Sugden and B.S. John, Glaciers and Landscape: a Geomorphological Approach, Edward Arnold, London (1988) 376pp.

Telford and Lamb, 1999 R.J. Telford and H.F. Lamb, Groundwater-mediated response to Holocene climatic change recorded by the diatom stratigraphy of an Ethiopian crater lake, Quaternary Research 52 (1999), pp. 63-75.

Turnbull and Davies, 2006 J.M. Turnbull and T.R.H. Davies, A mass movement origin for cirques, Earth Surface Processes and Landforms 31 (2006), pp. 1129-1148.

Troll, 1973 C. Troll, Das "Backbone of Africa" und die afrikanische Hauptlimascheide (Erläuterungen zu einer Karte), Bonner Meteorol. Abh. 17 (1973), pp. 209-222.

Umer et al., 2003 M. Umer, S. Kebede and H.A. Osmaston, Quaternary glacial activity on the Ethiopian Mountains. In: J. Ehlers and P.L. Gibbard, Editors, Quaternary Glaciations-Extent 
and Chronology, Part III: South America, Asia, Africa, Australia, Antartica, Elsevier, Amsterdam (2003), pp. 171-174.

Umer et al., 2007 Umer, M., Lamb, H., Bonnefille, R., Lézine, A.-M., Tiercelin, J.-J., Gibert, E., Cazet, J.P., Watrin, J., 2007. Late Pleistocene and Holocene vegetation history of the Bale Mountains, Ethiopia, Quaternary Science Reviews,.

Werdecker, 1962 J. Werdecker, Eine Durchquerung des Goba-Massivs in Südäthiopien, Hermann von Wissmann-Festschr. (1962), pp. 132-144.

Wesche, $2003 \mathrm{~K}$. Wesche, The importance of occasional droughts for Afroalpine landscape ecology, Journal of Tropical Ecology 19 (2003), pp. 197-208.

Winchester and Floyd, 1977 J.A. Winchester and P.A. Floyd, Geochemical discrimination of different magma series and their differentiation products using immobile elements, Chemical Geology 20 (1977), pp. 325-343. 


\section{Figures}



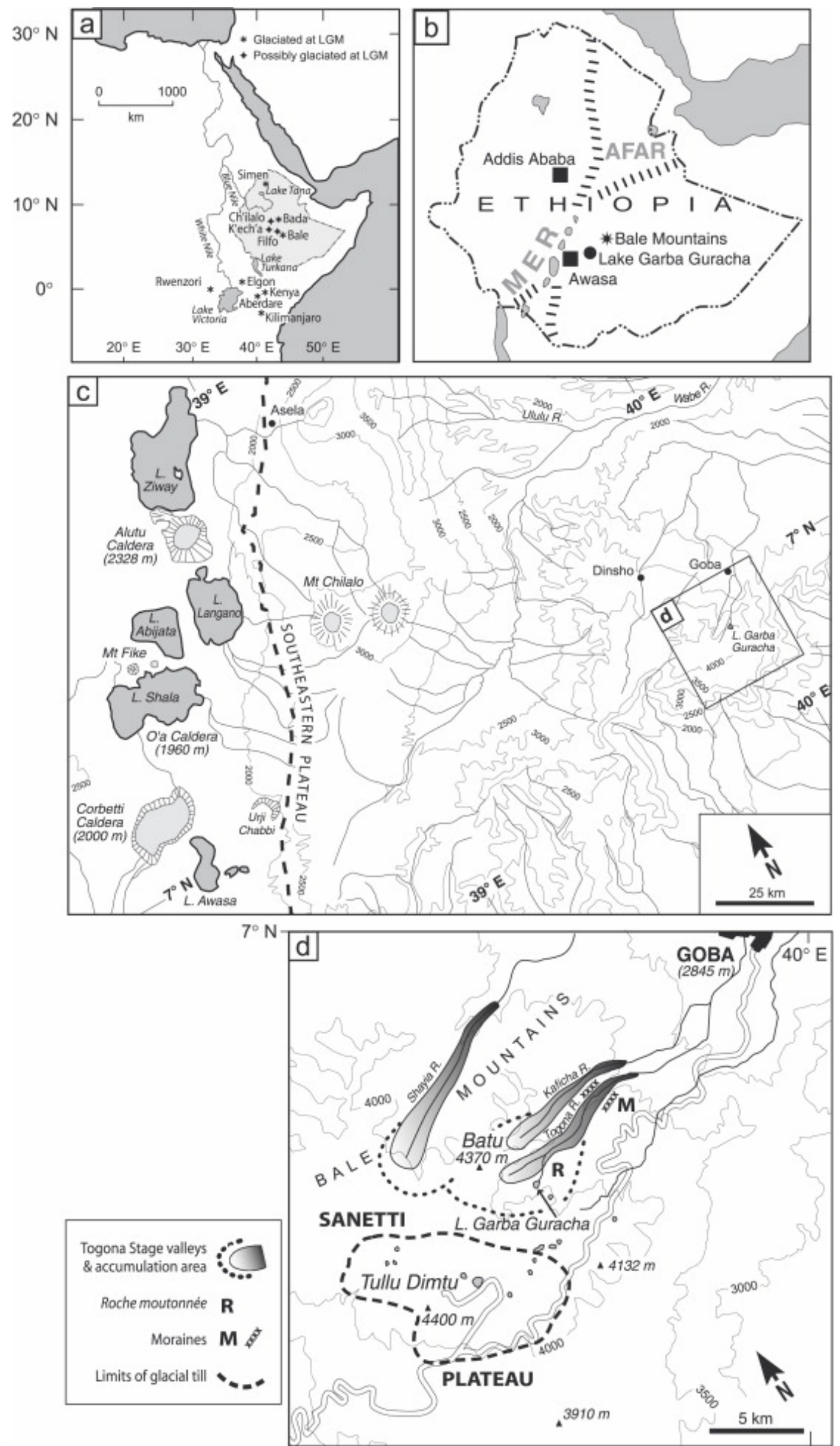
Fig. 1. (a) Location in East Africa of the main high-altitude sites glaciated at LGM or possibly glaciated at LGM. (b) The Main Ethiopian Rift (MER) and related high-altitude plateaus.

Location of Bale Mountains and Lake Garba Guracha. (c) Main physiographic features of the Main Ethiopian Rift and adjacent plateaus between $6^{\circ} 30^{\prime}$ and $8^{\circ} 15^{\prime}$ latitude North, showing the Ziway-Shala lake system on the rift floor and the location of Lake Garba Guracha in the Bale Mountains (redrawn from Ethiopia map, 1:1,000,000, Awasa, Series EMA 5, Sheet NB37, Edition 1, [Ethiopia map, 1999a] and [Ethiopia map, 1999b]; Ethiopia map, 1:250,000, Dodola, Series EMA 3, Sheet NB-37-7, Edition 2, [Ethiopia map, 1999a] and [Ethiopia map, 1999b]). (d) Location of Lake Garba Guracha within the hydrographic system of the Togona River. The glacial and periglacial features interpreted by Osmaston et al. (2005) in the Togona valley are indicated.
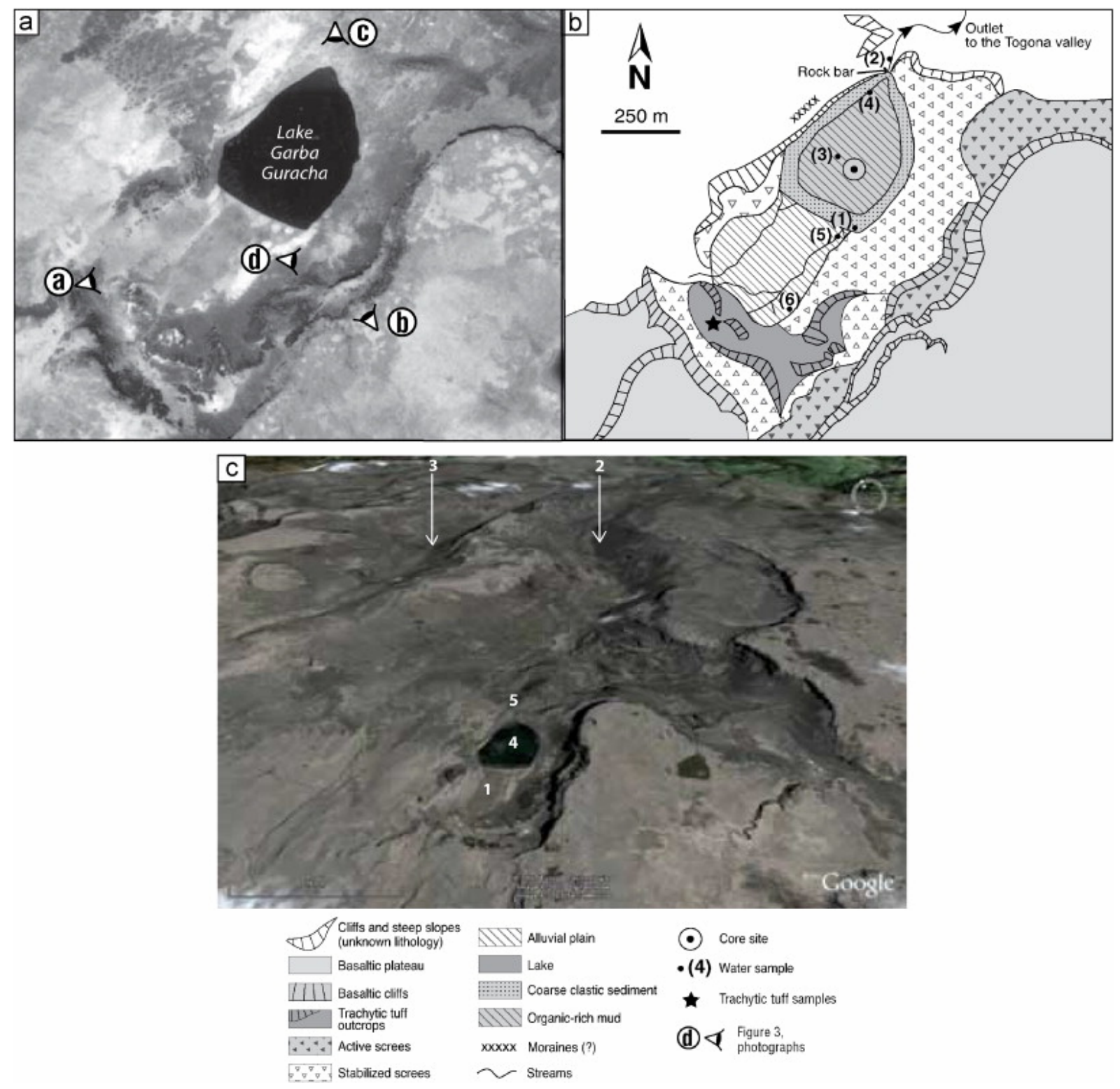
Fig. 2. (a) Aerial photograph (Bale Mountains, 17 January 1984, Ethiopian Mapping Authority). The location of photographs presented on Fig. 3 (a-d) is indicated. (b) Schematic geomorphological and sedimentological map of Lake Garba Guracha showing the location of the GG-I core site and water samples (from Ethiopia map, 1:50,000, Batu, Series ETH 4, Sheet 0639 B2, Edition 1, Ethiopian Mapping Authority, 2000). Outcrops of trachytic tuff forming the cirque floor are indicated as mapped from field observation and aerial and satellite imagery. (c) Oblique 3D view from the SW of the Garba Guracha cirque (1) at the end of a side valley connecting to the Togona River valley (2) that flows toward the northeast, parallel to the Kaficha River valley (3). These valleys show evidence of glacier occupation such as valley-bottom moraines and roches moutonnées (Osmaston et al., 2005). Lake Garba Guracha (4) lies in the northern part of the cirque and flows over a rock bar down the Togona valley (5) during periods of high lake level (Google Earth Image 4.2, August 2007).
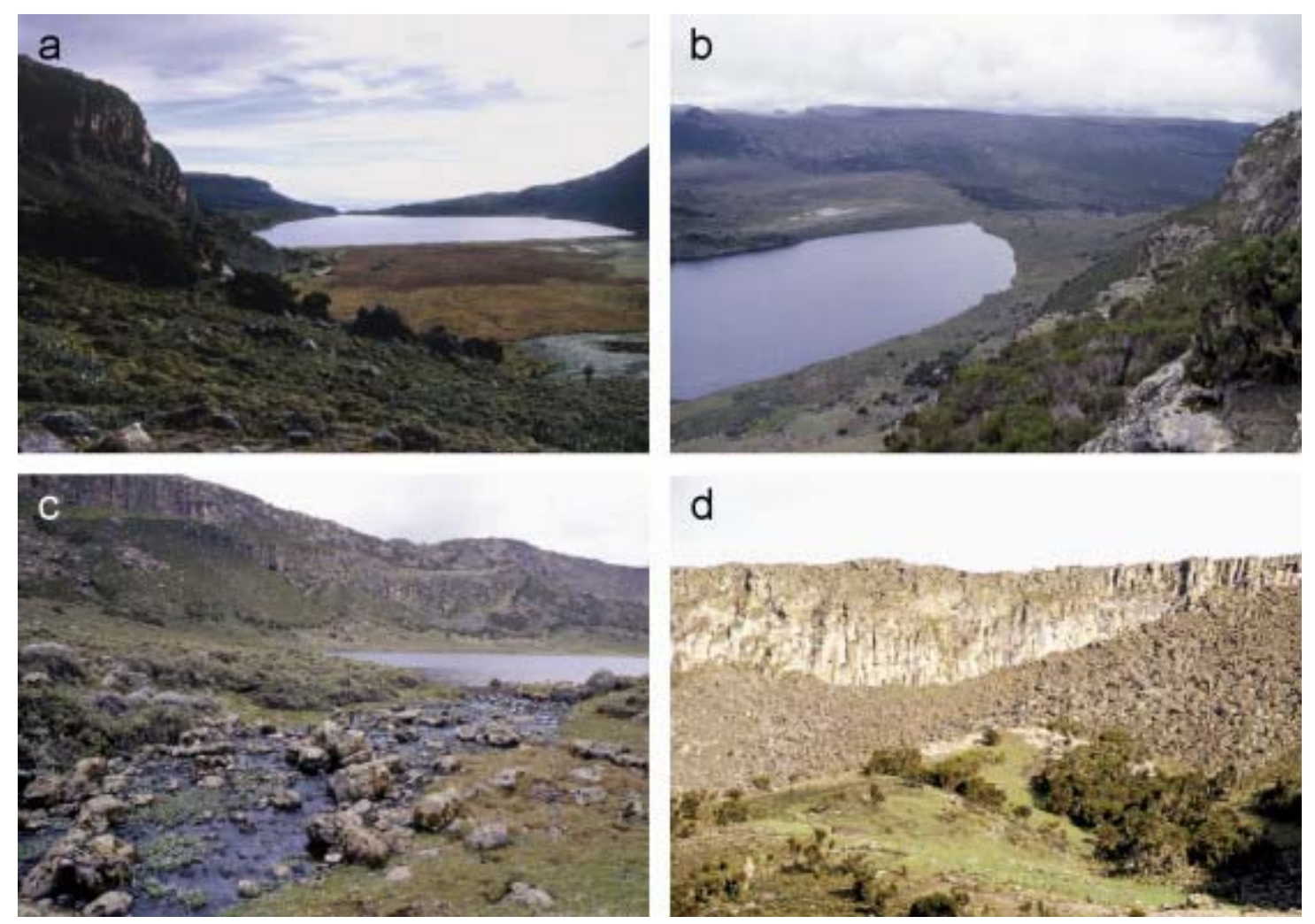

Fig. 3. (a) Lake Garba Guracha, upper Togona valley, Bale Mountains, looking northwards. The southern end of the basin is occupied by a $0.5 \mathrm{~km}$ long swampy deltaic plain characterized by a wide development of Cyperaceae and Juncus. (b) View of Lake Garba Guracha from the plateau (4100 m elevation), looking eastwards and northwards. A bouldercovered rock bar bounds the basin at its northern end. (c) This rock bar is slightly incised and acts as lake water outlet during maximum lake level phases, as it was the case in May 2001. (d) 140-m high basaltic cliffs and steep trachytic slopes bound the Garba Guracha cirque to the south and southeast. The eastern slopes of the cirque are partially covered by thick screes of basaltic debris. 


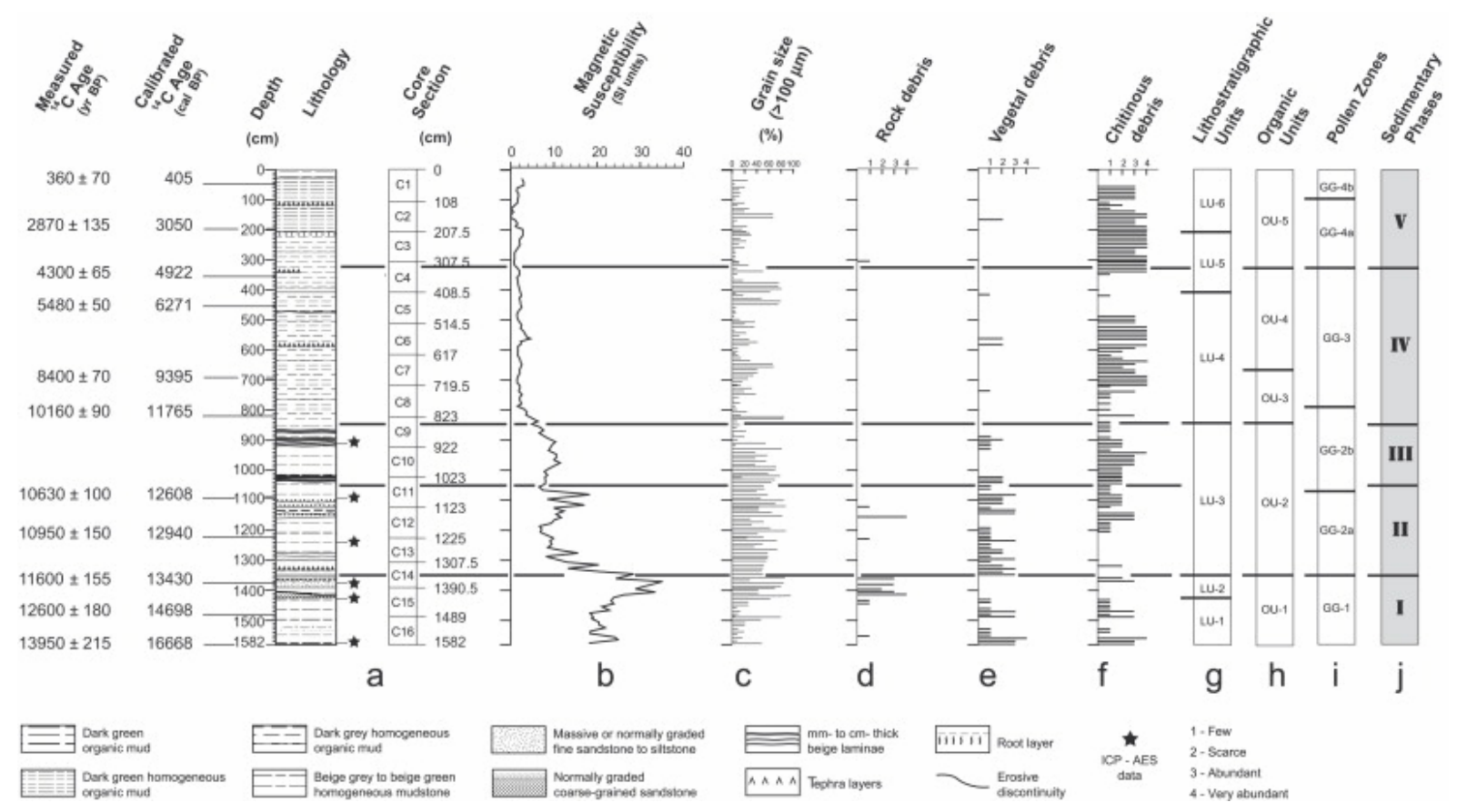

Fig. 4. (a) Lithologic log of the GG-I core showing the distribution of the main sedimentary facies and radiocarbon chronology. (b) Magnetic susceptibility curve. (c) Grain-size distribution of the $>100 \mu \mathrm{m}$ lithoclastic/bioclastic fraction. (d) Distribution of the $>100 \mu \mathrm{m}$ lithoclastic fraction (rock debris and minerals). (e, f) Distribution of the $>100 \mu \mathrm{m}$ bioclastic fraction (vegetal debris; chitinous debris). Semi-quantitative plots of sedimentological parameters have been obtained from $>100 \mu \mathrm{m}$ fraction analysis using optical binocular at magnification $\times 50$. (g) Lithostratigraphic units. (h) Organic units. (i) Pollen zones. (j) Sedimentary Phases.

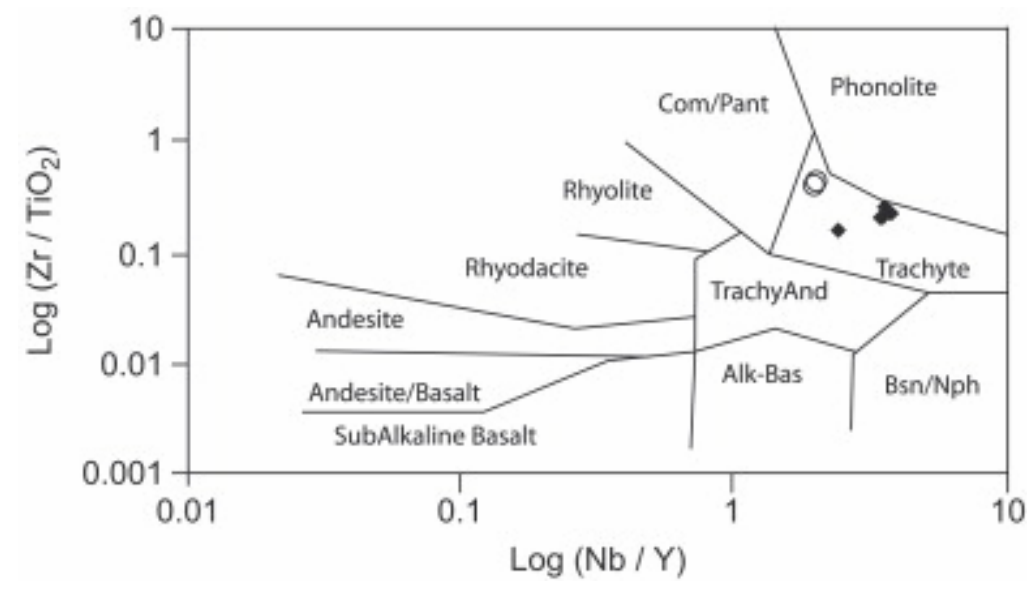

Fig. 5. $\log \left(\mathrm{Zr} / \mathrm{TiO}_{2}\right)$ vs. $\log (\mathrm{Nb} / \mathrm{Y})$ plots of the different igneous suites. Diagram after Winchester and Floyd (1977). Circles indicate the trachytic tuff samples and black squares the GG-I core sediment samples. 


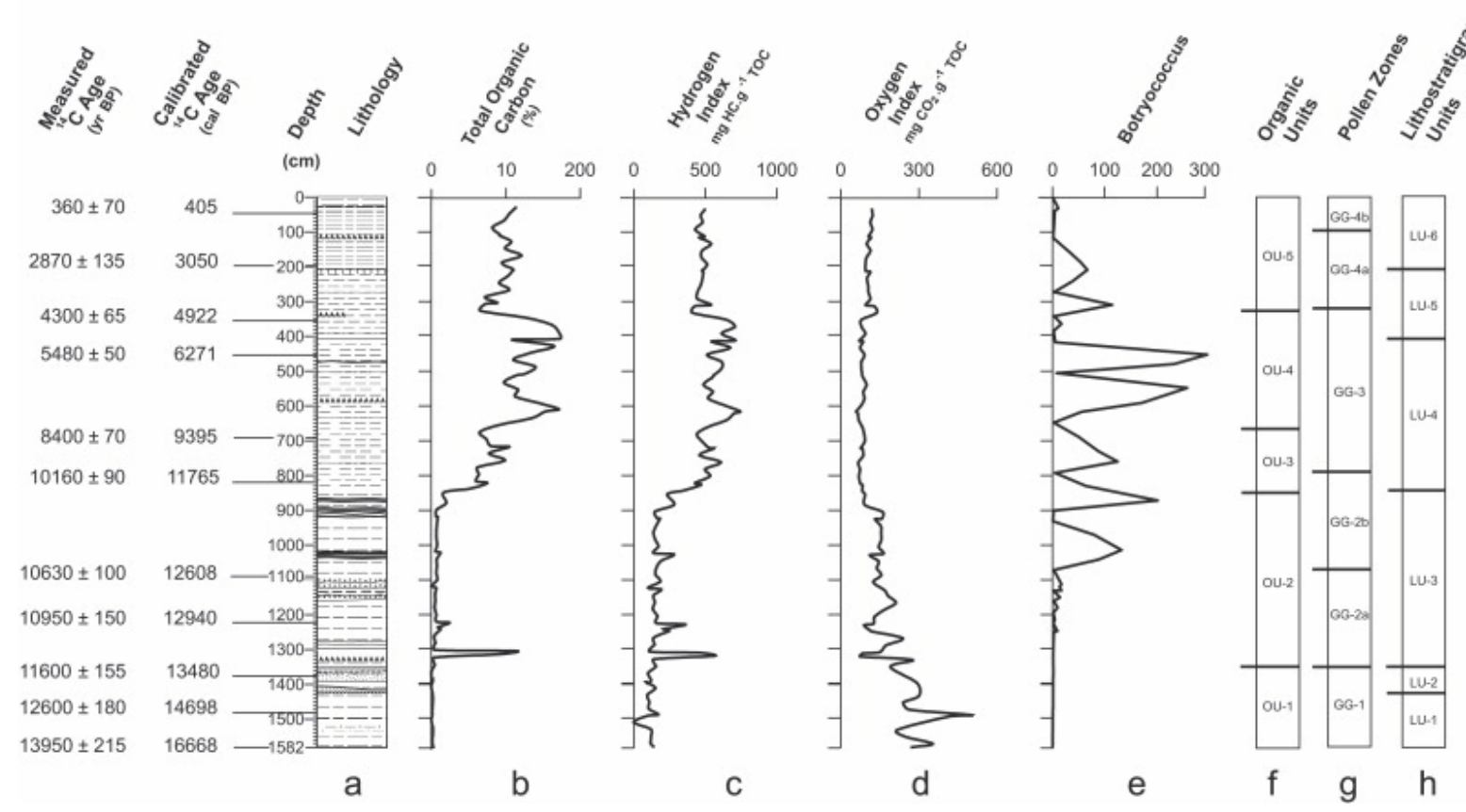

Fig. 6. Quantitative and qualitative variations of the sedimentary organic matter contents along the GG-I core. (a) TOC: Total Organic Carbon content. (b) and (c) HI and OI: RockEval®pyrolysis Hydrogen and Oxygen Indexes. (d) Variation of abundance of Botryococcus braunii.

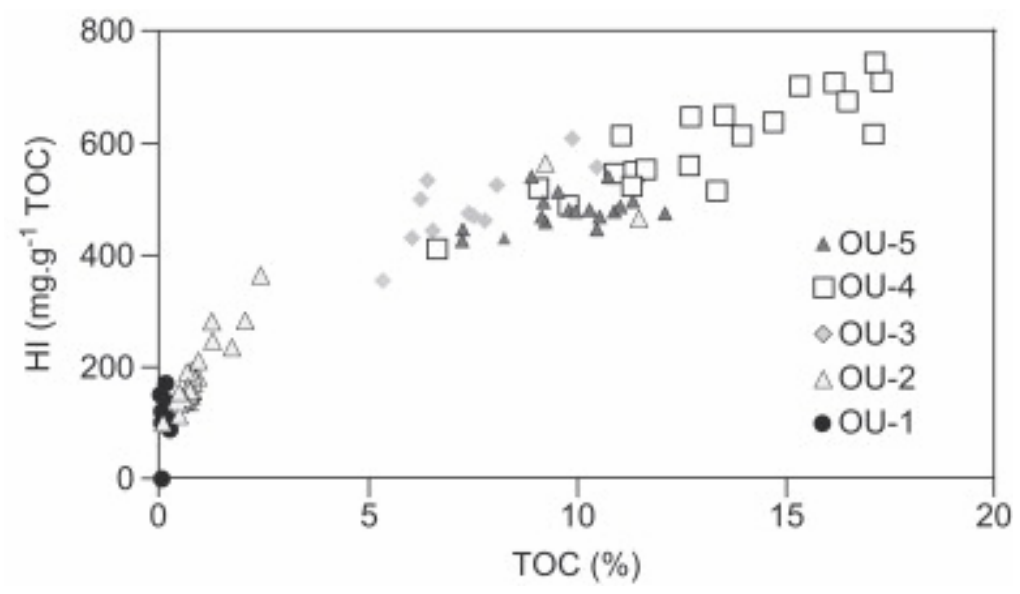

Fig. 7. HI vs. TOC diagram showing globally increasing OM quality (HI) with increasing quantity (TOC) in the organic units identified along the GG-I core (OU-1 to OU-5, from bottom to top; details in the discussion chapter). 


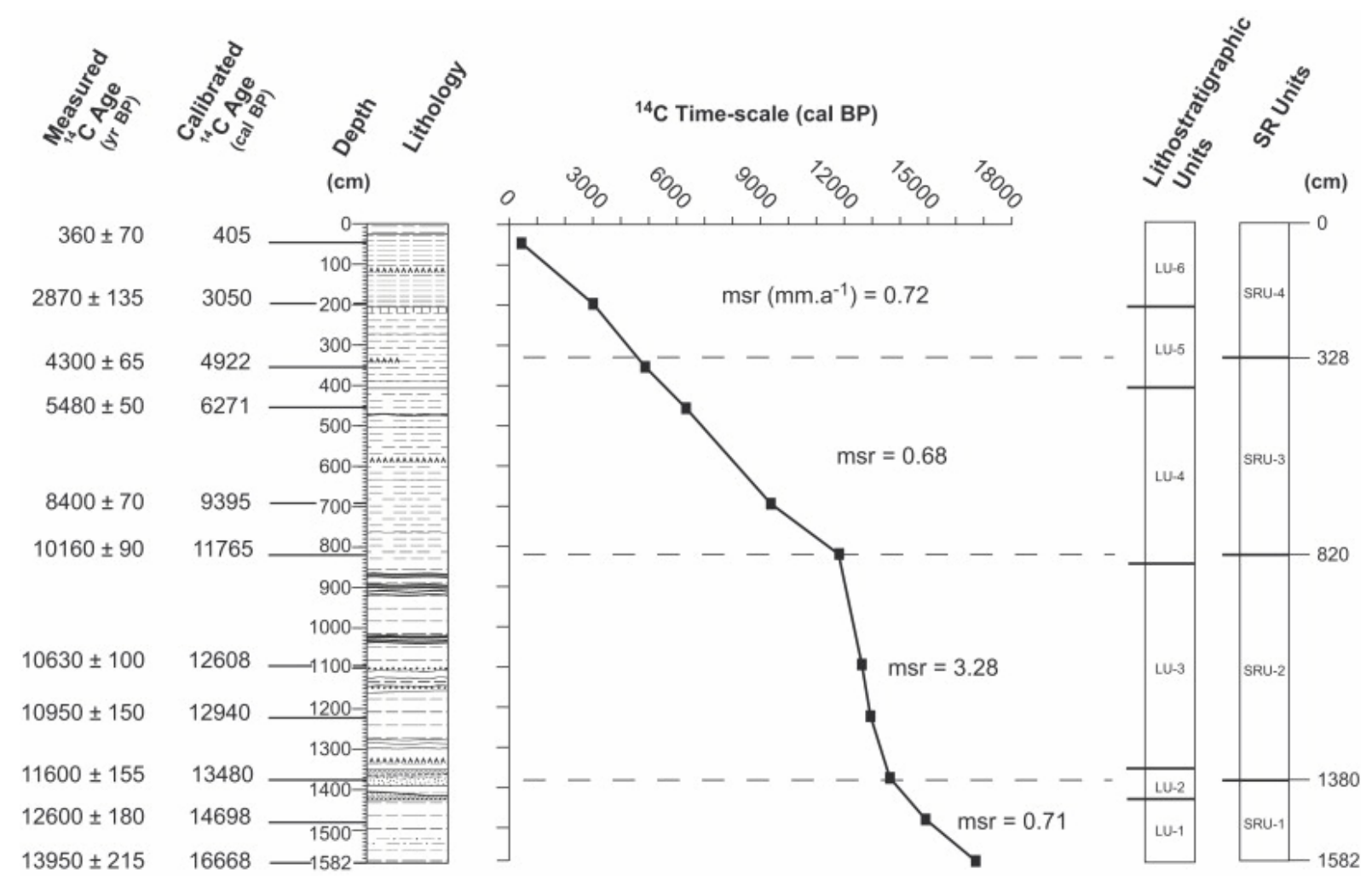

Fig. 8. Stratigraphic log of the GG-I core with calibrated ${ }^{14} \mathrm{C}$ time-scale and associated calculated mean sedimentation rate ( $\mathrm{msr}$ expressed in $\mathrm{mm} \mathrm{a}^{-1}$ ). 


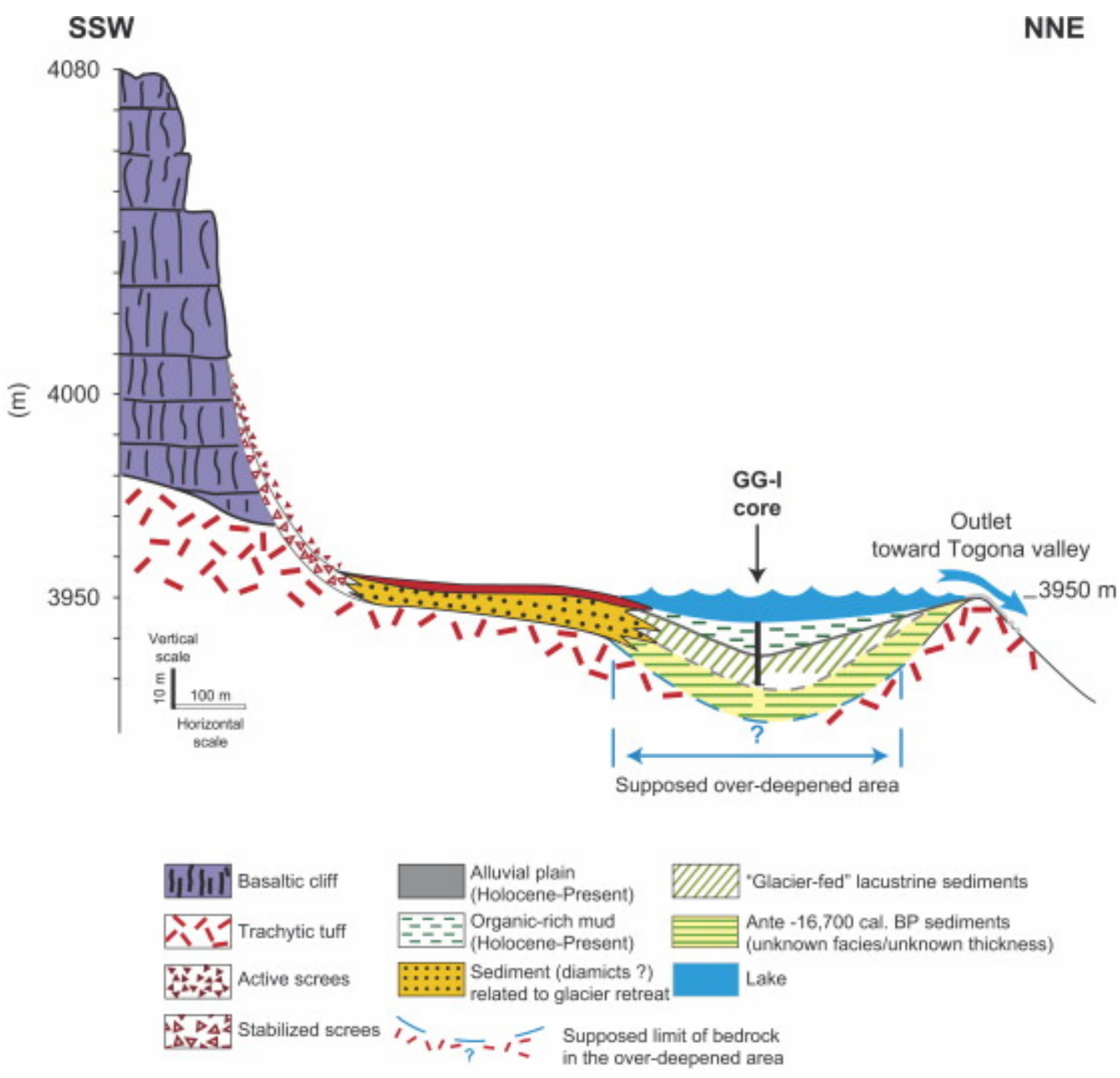

Fig. 9. Schematic SSW-NNE oriented geomorphological/geological cross-section of the Garba Guracha cirque, showing the possible over-deepening of the basin and supposed lithostratigraphy of the lake infill. 

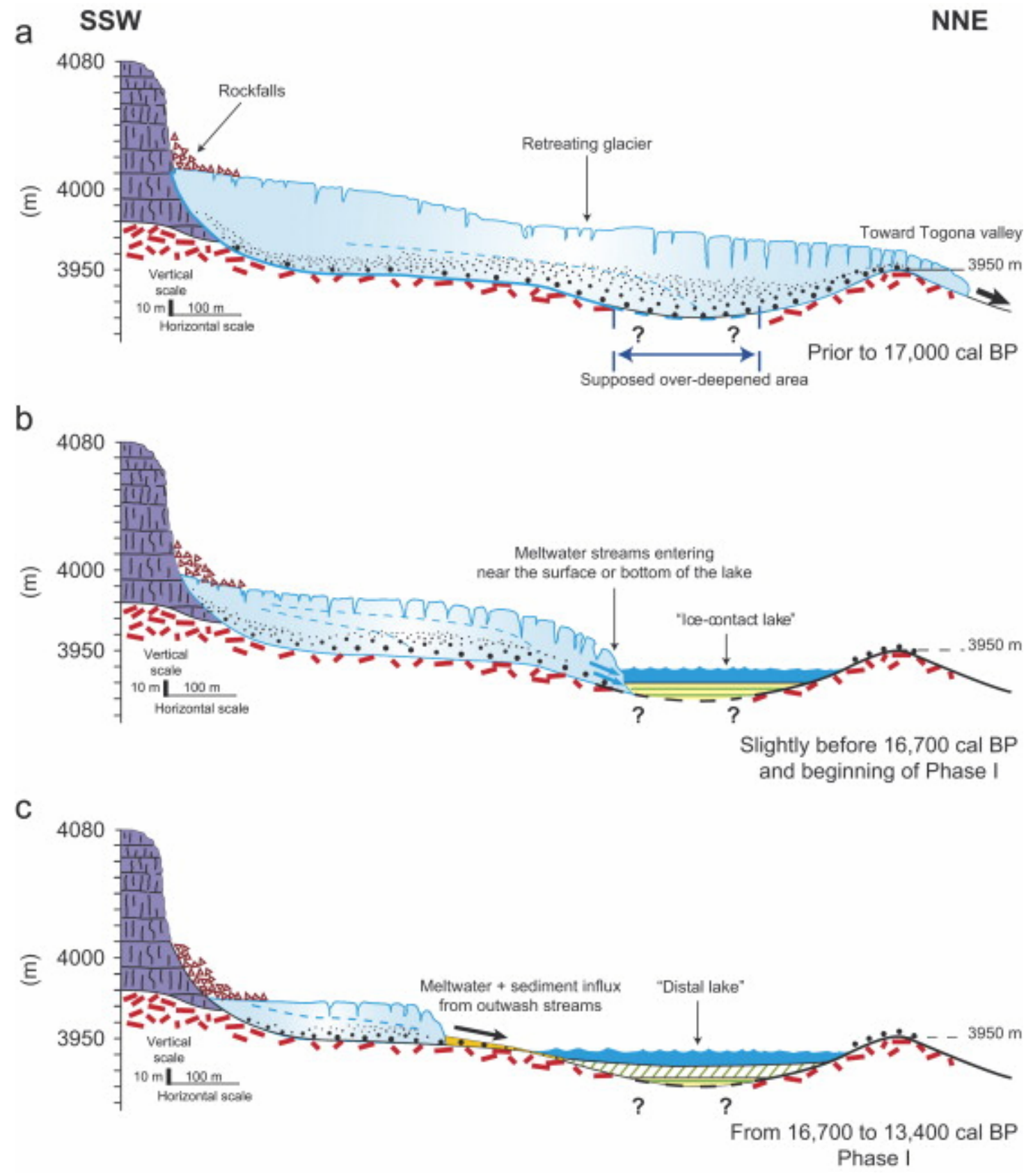

Fig. 10. Schematic SSW-NNE cross-sections over the Garba Guracha cirque illustrating successive stages of glacier recession in the cirque, with (a) initial stage of glacier recession within the Garba Guracha cirque; (b) development of an ice-contact lake filling the overdeepened part of the cirque; (c) transition from the ice-contact lake to a distal lake fed by outwash streams carrying meltwater and ice-trapped sediment; (d) and (e) last phases of ice lobe melting at the south end of the Garba Guracha cirque: acceleration of melting resulting in the complete filling of the lake and possible outlet initiation (d), followed by a decrease in meltwater and sediment influx (e) linked to disappearance of the ice lobe; (f) Postglacial lacustrine phase. 

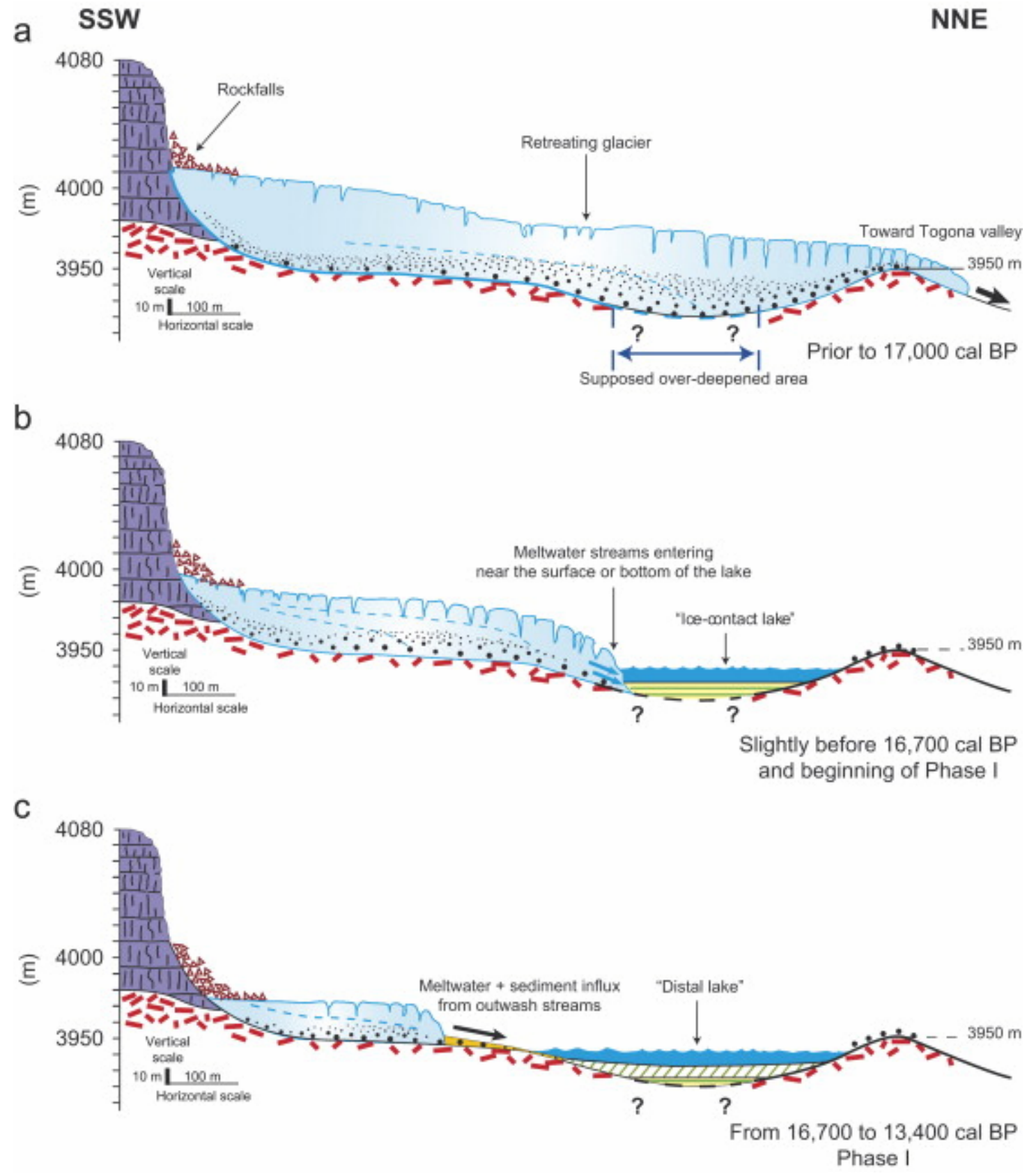

Fig. 10. Schematic SSW-NNE cross-sections over the Garba Guracha cirque illustrating successive stages of glacier recession in the cirque, with (a) initial stage of glacier recession within the Garba Guracha cirque; (b) development of an ice-contact lake filling the overdeepened part of the cirque; (c) transition from the ice-contact lake to a distal lake fed by outwash streams carrying meltwater and ice-trapped sediment; (d) and (e) last phases of ice lobe melting at the south end of the Garba Guracha cirque: acceleration of melting resulting in the complete filling of the lake and possible outlet initiation (d), followed by a decrease in meltwater and sediment influx (e) linked to disappearance of the ice lobe; (f) Postglacial lacustrine phase. 

Table 1. / Lake Garba Guracha and its watershed

\begin{tabular}{|c|c|c|c|c|c|c|c|c|c|c|c|c|c|c|c|c|}
\hline Sample & pH (field) & pH (Lab.) & $T\left({ }^{\circ} \mathbf{C}\right)$ & $\begin{array}{l}\mathrm{EC} \\
\left(\mu \mathrm{S} \mathrm{cm} \mathrm{cm}^{-1}\right) \\
\text { (Field) }\end{array}$ & $\begin{array}{l}\mathrm{EC} \\
\left(\mu \mathrm{S} \mathrm{cm} \mathrm{cm}^{-1}\right)(\text { Lab. })\end{array}$ & $\begin{array}{l}\text { TAC } \\
\left(\mathrm{mg} \mathrm{L}^{-1}\right)\end{array}$ & $\begin{array}{l}\mathrm{Na}^{+} \\
\left(\mathrm{mg} \mathrm{L}^{-1}\right)\end{array}$ & $\begin{array}{l}\mathrm{K}^{+} \\
\left(\mathbf{m g ~ L} \mathbf{L}^{-1}\right)\end{array}$ & $\begin{array}{l}\mathrm{Ca}^{2+} \\
\left(\mathrm{mg} \mathrm{L}^{-1}\right)\end{array}$ & $\begin{array}{l}\mathrm{Mg}^{2+} \\
\left(\mathrm{mg} \mathrm{L}^{-1}\right)\end{array}$ & $\begin{array}{l}\mathrm{HCO}_{3}^{-} \\
\left(\mathrm{mg} \mathrm{L}^{-1}\right)\end{array}$ & $\begin{array}{l}\mathrm{CO}_{3}{ }^{2-} \\
\left(\mathrm{mg} \mathrm{L}^{-1}\right)\end{array}$ & $\begin{array}{l}\mathrm{Cl}^{-} \\
\left(\mathrm{mg} \mathrm{L} \mathrm{L}^{-1}\right)\end{array}$ & $\begin{array}{l}\mathrm{SO}_{4}{ }^{2-} \\
\left(\mathrm{mg} \mathrm{L}^{-1}\right)\end{array}$ & $\begin{array}{l}\mathbf{F}^{-} \\
\left(\mathbf{m g ~ L}^{-1}\right)\end{array}$ & $\begin{array}{l}\mathrm{NO}_{3}^{-} \\
\left(\mathrm{mg} \mathrm{L}^{-1}\right)\end{array}$ \\
\hline \multicolumn{17}{|l|}{ (a) } \\
\hline $\begin{array}{l}1 \text { (River } \\
\text { mouth) }\end{array}$ & & 6.77 & & & 57.8 & & 7.08 & 1.21 & 3.04 & 0.69 & 29 & - & 1.63 & 1.64 & $<$ & $<$ \\
\hline 2 & 7.05 & 6.95 & 13.8 & 76.8 & 56.7 & & 6.79 & 1.19 & 2.83 & 0.63 & 27 & - & 0.49 & 0.45 & $<$ & $<$ \\
\hline $\begin{array}{l}3 \text { (Core } \\
\text { site) }\end{array}$ & 6.93 & 6.91 & & & 58.0 & & 6.92 & 1.21 & 3.09 & 0.67 & 28 & & 1.68 & 1.63 & $<$ & $<$ \\
\hline $\begin{array}{l}4 \text { (South } \\
\text { shore) }\end{array}$ & & 6.90 & & & 56.7 & & 7.07 & 1.15 & 2.90 & 0.62 & 28 & & 1.67 & 1.55 & $<$ & $<$ \\
\hline 5 (INPUT) & & 6.81 & & & 53.0 & & 8.31 & 1.05 & 1.95 & 0.35 & 28 & & 1.10 & 0.95 & 0.06 & 0.09 \\
\hline \multirow[t]{2}{*}{6 (Swamp) } & 7.3 & 6.84 & 11.5 & 77.0 & 62.2 & & 8.06 & 0.87 & 2.88 & 0.59 & 27 & & 1.84 & 2.48 & 0.10 & 3.41 \\
\hline & IS Calcite & $\begin{array}{l}\text { IS } \\
\text { Dolomite }\end{array}$ & $\begin{array}{l}\text { IS } \\
\text { Gypsum }\end{array}$ & $\begin{array}{l}\text { IS } \\
\text { Aragonite }\end{array}$ & IS Fluorite & $\begin{array}{l}\text { IS } \\
\text { Anydrite }\end{array}$ & & & & & & & & & & \\
\hline \multicolumn{7}{|l|}{ (b) } & & & & & & & & & & \\
\hline $\begin{array}{l}1 \text { (River } \\
\text { mouth) }\end{array}$ & -2.35 & -5.52 & -4.38 & -2.68 & - & -4.74 & & & & & & & & & & \\
\hline $\begin{array}{l}2 \\
\text { (OUTPUT) }\end{array}$ & -2.58 & -5.65 & -4.97 & -2.74 & - & -5.32 & & & & & & & & & & \\
\hline $\begin{array}{l}3 \text { (Core } \\
\text { site) }\end{array}$ & -2.54 & -5.56 & -4.38 & -2.69 & - & -4.73 & & & & & & & & & & \\
\hline 4 (South & -2.56 & -5.62 & -4.42 & -2.72 & - & -4.78 & & & & & & & & & & \\
\hline
\end{tabular}




\begin{tabular}{|c|c|c|c|c|c|c|c|c|c|c|c|c|c|c|c|c|}
\hline Sample & pH (field) & pH (Lab.) & $T\left({ }^{\circ} \mathrm{C}\right)$ & $\begin{array}{l}\mathrm{EC} \\
\left(\mu \mathrm{S} \mathrm{cm}{ }^{-1}\right) \\
\text { (Field) }\end{array}$ & $\begin{array}{l}\text { EC } \\
\left(\mu \mathrm{S} \mathrm{cm}{ }^{-1}\right)(\text { Lab. })\end{array}$ & $\begin{array}{l}\text { TAC } \\
\left(\mathrm{mg} \mathrm{L}^{-1}\right)\end{array}$ & $\begin{array}{l}\mathrm{Na}^{+} \\
\left(\mathrm{mg} \mathrm{L}^{-1}\right)\end{array}$ & $\begin{array}{l}\mathrm{K}^{+} \\
\left(\mathrm{mg} \mathrm{L}^{-1}\right)\end{array}$ & $\begin{array}{l}\mathrm{Ca}^{2^{+}} \\
\left(\mathrm{mg} \mathrm{L}^{-1}\right)\end{array}$ & $\begin{array}{l}\mathbf{M g}^{2+} \\
\left(\mathbf{m g ~ L}^{-1}\right)\end{array}$ & $\begin{array}{l}\mathrm{HCO}_{3}^{-} \\
\left(\mathrm{mg} \mathrm{L}^{-1}\right)\end{array}$ & $\begin{array}{l}\mathrm{CO}_{3}^{2-} \\
\left(\mathrm{mg} \mathrm{L}^{-1}\right)\end{array}$ & $\begin{array}{l}\mathrm{Cl}^{-} \\
\left(\mathrm{mg} \mathrm{L}^{-1}\right)\end{array}$ & $\begin{array}{l}\mathrm{SO}_{4}^{2^{-}} \\
\left(\mathrm{mg} \mathrm{L}^{-1}\right)\end{array}$ & $\begin{array}{l}\mathbf{F}^{-} \\
\left(\mathbf{m g ~ L}^{-1}\right)\end{array}$ & $\begin{array}{l}\mathrm{NO}_{3}^{-} \\
\left(\mathrm{mg} \mathrm{L}^{-1}\right)\end{array}$ \\
\hline \multicolumn{17}{|l|}{ shore) } \\
\hline 5 (INPUT) & -2.73 & -6.03 & -4.80 & -2.88 & -4.29 & -5.16 & & & & & & & & & & \\
\hline \multirow[t]{2}{*}{6 (Swamp) } & -2.32 & -5.18 & -4.22 & -2.47 & -3.66 & -4.61 & & & & & & & & & & \\
\hline & \begin{tabular}{|l}
$\delta^{18} O_{\text {surface }}$ \\
water (\% vs. \\
SMOW)
\end{tabular} & \begin{tabular}{|l}
$\delta^{2} \mathbf{H}_{\text {surface }}$ \\
water $(\%$ vs. \\
SMOW)
\end{tabular} & & & & & & & & & & & & & & \\
\hline \multicolumn{17}{|l|}{ (c) } \\
\hline $\begin{array}{l}1 \text { (River } \\
\text { mouth) }\end{array}$ & - & - & & & & & & & & & & & & & & \\
\hline $\begin{array}{l}2 \\
\text { (OUTPUT) }\end{array}$ & +2.2 & 20.4 & & & & & & & & & & & & & & \\
\hline $\begin{array}{l}3 \text { (Core } \\
\text { site) }\end{array}$ & \multicolumn{2}{|c|}{ (not enough water) } & & & & & & & & & & & & & & \\
\hline $\begin{array}{l}4 \text { (South } \\
\text { shore) }\end{array}$ & +1.8 & 19.9 & & & & & & & & & & & & & & \\
\hline 5 (INPUT) & -2.2 & 0.1 & & & & & & & & & & & & & & \\
\hline 6 (Swamp) & +1.2 & 3.4 & & & & & & & & & & & & & & \\
\hline
\end{tabular}

(a) Chemical analyses of surface waters; (b) saturation indices for major minerals; (c) stable isotope contents of surface waters. Sampling time: May 2001. See Fig. 2 for sample location. Water analyses were performed in the Laboratory of Hydrogeology of the University of Avignon (France). Anions and cations were determined by ionic chromatography (Dionex DX 120) and atomic absorption spectrometry (Varian 640) with an analytical precision of $4 \%$ and $2 \%$, respectively. 
Table 2. :Major and trace element data for sediments of the GG-I core between 1582 and $843 \mathrm{~cm}$ and for the trachytic tuff forming the Garba Guracha cirque base

\begin{tabular}{|c|c|c|c|c|c|c|c|c|c|}
\hline Core depth & 911.5 & 1103.5 & 1240.5 & 1368 & 1431 & 1579.5 & Trachyte & GG2001/A & GG2001/B \\
\hline $\mathrm{SiO}_{2}(\mathrm{wt} \%)$ & 72.83 & 73.06 & 97.42 & 68.42 & 69.96 & 70.72 & & 58.45 & 61.08 \\
\hline $\mathrm{TiO}_{2}$ & 0.65 & 0.65 & 0.94 & 0.51 & 0.61 & 0.59 & & 0.34 & 0.35 \\
\hline $\mathrm{Al}_{2} \mathrm{O}_{3}$ & 21.62 & 21.45 & 25.26 & 20.38 & 20.68 & 20.87 & & 17.62 & 17.87 \\
\hline $\mathrm{Fe}_{2} \mathrm{O}_{3}$ & 6.65 & 6.56 & 8.68 & 5.58 & 6.30 & 5.93 & & 7.01 & 6.79 \\
\hline $\mathrm{MnO}$ & 0.25 & 0.28 & 0.40 & 0.45 & 0.30 & 0.28 & & 2.04 & 0.45 \\
\hline $\mathrm{MgO}$ & 0.72 & 0.67 & 1.22 & 0.37 & 0.62 & 0.62 & & 0.43 & 0.63 \\
\hline $\mathrm{CaO}$ & 1.64 & 1.66 & 2.00 & 1.30 & 1.66 & 1.71 & & 0.58 & 0.85 \\
\hline $\mathrm{Na}_{2} \mathrm{O}$ & 3.49 & 3.54 & 1.71 & 5.31 & 4.50 & 4.49 & & 7.33 & 6.33 \\
\hline $\mathrm{K}_{2} \mathrm{O}$ & 5.51 & 5.79 & 4.56 & 6.83 & 6.24 & 6.23 & & 5.14 & 4.86 \\
\hline $\mathrm{P}_{2} \mathrm{O}_{5}$ & 0.18 & 0.14 & 0.37 & 0.10 & 0.12 & 0.11 & & 0.07 & 0.08 \\
\hline $\mathrm{Rb}(\mathrm{ppm})$ & 195.0 & 191.5 & 165.5 & 164.2 & 170.6 & 176.2 & & 257.2 & 161.9 \\
\hline $\mathrm{Sr}$ & 80.3 & 78.0 & 120.9 & 91.4 & 82.5 & 80.8 & & 51.4 & 288.1 \\
\hline $\mathrm{Ba}$ & 114.7 & 111.3 & 266.2 & 83.7 & 99.2 & 117.9 & & 27.4 & 14.5 \\
\hline $\mathrm{Sc}$ & 3.4 & 3.4 & 9.1 & 1.3 & 3.2 & 3.1 & & 1.6 & 15.6 \\
\hline V & 16.1 & 14.9 & 54.7 & 5.5 & 12.3 & 12.3 & & 2.2 & 3.4 \\
\hline $\mathrm{Cr}$ & 17.2 & 18.4 & 63.3 & 7.7 & 19.0 & 21.3 & & 3.3 & 2.2 \\
\hline Co & 3.4 & 3.4 & 8.6 & 1.1 & 2.2 & 2.2 & & 1.1 & 1.1 \\
\hline $\mathrm{Ni}$ & 13.8 & 10.9 & 36.0 & 3.3 & 8.9 & 9.5 & & 1.1 & 2.2 \\
\hline Y & 112.4 & 113.5 & 165.5 & 101.4 & 105.4 & 97.1 & & 120.4 & 120.6 \\
\hline $\mathrm{Zr}$ & 1296.0 & 1319.0 & 1439.1 & 1267.1 & 1304.5 & 1260.5 & & 1422.9 & 1306.5 \\
\hline $\mathrm{Nb}$ & 390.0 & 401.4 & 402.9 & 363.6 & 385.8 & 364.8 & & 246.3 & 241.2 \\
\hline $\mathrm{La}$ & 239.7 & 250.0 & 293.6 & 229.2 & 239.7 & 225.6 & & 291.2 & 284.8 \\
\hline $\mathrm{Ce}$ & 418.6 & 441.6 & 520.9 & 401.1 & 418.1 & 398.5 & & 468.5 & 480.2 \\
\hline $\mathrm{Nd}$ & 133.0 & 142.2 & 185.6 & 128.9 & 136.0 & 126.8 & & 151.1 & 147.4 \\
\hline $\mathrm{Sm}$ & 22.3 & 23.2 & 31.7 & 20.7 & 22.0 & 20.5 & & 25.2 & 24.1 \\
\hline $\mathrm{Eu}$ & 2.4 & 2.5 & 3.8 & 2.1 & 2.3 & 2.2 & & 2.3 & 2.3 \\
\hline
\end{tabular}




\begin{tabular}{|l|l|l|l|l|l|l|l|l|l|}
\hline Core depth & $\mathbf{9 1 1 . 5}$ & $\mathbf{1 1 0 3 . 5}$ & $\mathbf{1 2 4 0 . 5}$ & $\mathbf{1 3 6 8}$ & $\mathbf{1 4 3 1}$ & $\mathbf{1 5 7 9 . 5}$ & Trachyte & GG2001/A & GG2001/B \\
\hline $\mathrm{Gd}$ & 17.5 & 18.4 & 25.3 & 15.6 & 17.2 & 16.3 & & 18.2 & 18.9 \\
\hline $\mathrm{Dy}$ & 17.7 & 18.6 & 25.8 & 16.3 & 17.1 & 15.5 & & 18.6 & 19.7 \\
\hline $\mathrm{Er}$ & 11.4 & 11.5 & 16.3 & 10.0 & 10.5 & 9.7 & & 10.9 & 11.7 \\
\hline $\mathrm{Yb}$ & 11.0 & 11.2 & 16.4 & 10.3 & 10.4 & 9.7 & & 10.9 & 11.6 \\
\hline $\mathrm{Th}$ & 45.9 & 47.6 & 51.8 & 42.4 & 45.7 & 43.8 & & 50.4 & 50.3 \\
\hline $\mathrm{Y} / \mathrm{Ni}$ & 8.2 & 10.4 & 4.6 & 30.7 & 11.8 & 10.2 & & 110.0 & 54.0 \\
\hline
\end{tabular}

All major elements in weight percent and trace elements in ppm. 
Table 3. : Lake Garba Guracha: measured and calibrated AMS radiocarbon datings (cal BP; Stuiver et al., CALIB5.0.2, 2005), and associated $\delta^{13} \mathrm{C}$

\begin{tabular}{|c|c|c|c|c|c|c|c|c|}
\hline $\begin{array}{l}\text { Depth in } \\
\text { core sub- } \\
\text { section }\end{array}$ & $\begin{array}{l}\text { Core sub- } \\
\text { section }\end{array}$ & $\begin{array}{l}\text { Core } \\
\text { depth } \\
\text { (cm) }\end{array}$ & Type & $\begin{array}{l}\text { Analyse Nr } \\
\left({ }^{14} \mathrm{C} \text {-Orsay) }\right.\end{array}$ & $\begin{array}{l}{ }^{14} \mathrm{C} \text { activity } \\
\text { (pmc) }\end{array}$ & $\begin{array}{l}\text { Measured }{ }^{14} \mathrm{C} \\
\text { age (yr BP) }\end{array}$ & $\begin{array}{l}\text { Calibrated }{ }^{14} \mathrm{C} \\
\text { ages }(\mathrm{yr} \mathrm{BP})\left({ }^{*}\right)\end{array}$ & $\begin{array}{l}\delta^{13} \mathrm{C}(\% \\
\text { vs. PDB) }\end{array}$ \\
\hline $47-48$ & 1 & $47-48$ & TOM & H2735 & $95.64 \pm 0.81$ & $360 \pm 70$ & 405 & -16.5 \\
\hline 90 & 2 & 198 & TOM & $\mathrm{H} 2816$ & $69.94 \pm 1.16$ & $2870 \pm 135$ & 3050 & $\begin{array}{l}\text { (not } \\
\text { enough } \\
\text { gas) }\end{array}$ \\
\hline 50 & 4 & 357.5 & TOM & H2815 & $58.56 \pm 0.46$ & $4300 \pm 65$ & 4922 & $\begin{array}{l}\text { (not } \\
\text { enough } \\
\text { gas) }\end{array}$ \\
\hline $45-46$ & 5 & 454 & TOM & H3260 & $50.53 \pm 0.34$ & $5480 \pm 50$ & 6271 & \\
\hline $74-75$ & 7 & 691.5 & TOM & H3261 & $35.15 \pm 0.30$ & $8400 \pm 70$ & 9395 & \\
\hline $100-101$ & 8 & $\begin{array}{l}819.5- \\
820.5\end{array}$ & TOM & H2736 & $28.22 \pm 0.30$ & $10,160 \pm 90$ & 11,765 & -20.8 \\
\hline $70-71$ & 11 & $\begin{array}{l}1093- \\
1094\end{array}$ & TOM & H2737 & $26.60 \pm 0.40$ & $10,630 \pm 100$ & 12,608 & -16.3 \\
\hline $100-101$ & 12 & $\begin{array}{l}1223- \\
1224\end{array}$ & TOM & H2738 & $25.58 \pm 0.47$ & $10,950 \pm 150$ & 12,940 & -16.0 \\
\hline $80-81$ & 14 & $\begin{array}{l}1377.5- \\
1378.5\end{array}$ & TOM & H2739 & $23.59 \pm 0.45$ & $11,600 \pm 155$ & 13,480 & -14.6 \\
\hline $90-91$ & 15 & 1480 & TOM & $\mathrm{H} 2740$ & $20.84 \pm 0.47$ & $12,600 \pm 180$ & 14,698 & -11.9 \\
\hline $85-90$ & 16 & & TOM & $\beta-159372$ & & $(11,480 \pm 50)$ & $(13,427)$ & -20.3 \\
\hline $90-91$ & 16 & $\begin{array}{l}1579- \\
1580\end{array}$ & TOM & H2817 & $17.62 \pm 0.47$ & $13,950 \pm 215$ & 16,668 & $\begin{array}{l}\text { (not } \\
\text { enough } \\
\text { gas) }\end{array}$ \\
\hline
\end{tabular}

See Fig. 4 for core description and sample locations.

TOM:Total Organic Matter. Error bars represent one sigma deviation.

Accuracies on ${ }^{13} \mathrm{C}$ measurements are of $\pm 0.05 \%$ PDB for organic matter.

(*) CALIB 5.0.2html*, Copyright 1986-2005 M. Stuiver and P.J. Reimer. * to be used in conjunction with: Stuiver M and Reimer PJ, 1993. Radiocarbon 35, 215-230.

Including: (1) Stuiver M, Pearson G.W. 1993. Radiocarbon, 35, 1-23; (2) Pearson GW, Stuiver M. 1993. Radiocarbon, 35, 25-33; (3) Pearson GW, Becker B, Qua F. 1993.

Radiocarbon, 35, 93-104; (4) Linick TW, Long A, Damon PE, Ferguson CW. 1993.

Radiocarbon, 35, 943-953; (5) Kromer B, Becker B. 1993. Radiocarbon, 35, 125-135; (6) Bard E, Arnold M, Fairbanks RG, Hamelin B. 1993. Radiocarbon, 35, 191-199; (4) Pearson GW, Stuiver M. 1993. Radiocarbon, 35, 25-33. 